\title{
International Financial Flows in the New Normal: Key Patterns (and Why We Should Care) $)^{1}$
}

\author{
Matthieu Bussière`, Julia Schmidt* \& Natacha Valla*
}

\section{Summary}

This policy brief documents recent trends in international financial flows, based on a newly assembled dataset covering 40 advanced and emerging countries. Specifically, we compare the period since 2012 with the pre-crisis period and highlight four key stylized facts. First, the "Great Retrenchment" that took place during the crisis has proved very persistent, and world financial flows are now down to half their pre-crisis levels. Second, this fall can predominantly be related to advanced economies, especially those in Western Europe, while emerging markets, except Eastern European countries, have been less severely affected until recently. Third, the global patterns of net flows have also recorded significant changes. Overall, net flows have fallen substantially relative to the years preceding the sudden stop, which is to some extent an expression of the changes registered in the current account. Fourth, not all types of flows have shown the same degree of resilience, resulting in a profound change in the composition of international financial flows: while banking flows, which used to account for the largest share of the total before 2008, have collapsed, FDI flows have been barely affected and now represent roughly 45\% of global flows. Portfolio flows stand between these two extremes, and within them equity flows have proved more robust than debt flows, which should help to strengthen resilience and deliver genuine cross-border risk-sharing. Having highlighted these stylized facts, this policy brief turns to possible explanations for and likely implications of these changes, regarding international financial stability issues.

(1) The views expressed in this document are those of the authors and do not necessarily reflect those of the Banque de France or the Eurosystem. We are very grateful to Valérie Ghiringhelli and Valérie Vogel for outstanding research assistance, and to Jonas Heipertz for additional help. We would like to thank Olivier Blanchard, John Bluedorn, Claudia Buch, Bruno Cabrillac, Menzie Chinn, Aitor Erce, Ludovic Gauvin, Jean-Baptiste Gossé, Pierre-Olivier Gourinchas Galina Hale, Romain Lafarguette, Arnaud Mehl, Gian Maria Milesi-Ferretti, François Mouriaux, Damien Puy, Julio Ramos-Tallada, Romain Rancière, Cédric Tille, Miklos Vari and Frank Warnock for helpful comments and discussions. The appendix containing many additional charts and tables can be downloaded and consulted online under the following link: http://www.cepii.fr/CEPII/fr/publications/pb/abstract.asp?NoDoc=8956

- Matthieu Bussière, Banque de France, 31 rue Croix des Petits Champs, 75001, Paris, France. Matthieu.bussiere@banque-france.fr. Corresponding author.

- Julia Schmidt, Banque de France. Julia.schmidt@banque-france.fr.

- Natacha Valla, CEPII, 113, rue de Grenelle, 75007 Paris, France. Natacha.valla@eui.eu and Natacha.valla@cepii.fr. 


\section{Introduction}

International financial flows play a central role in the international monetary system, not just because they represent the necessary counterpart to trade flows. In good times, they channel savings to the countries and regions of the world where they are most productive. In crisis times, they have the potential to disrupt the domestic financial systems of the most vulnerable countries and therefore constitute a key factor affecting global financial stability. International financial flows also represent one of the corner stones of the contemporary "dilemmas" and "trilemmas" that link monetary policy, exchange rates and the capital account (Rey, 2013). Together with trade flows, international capital flows act as a powerful channel through which domestic shocks are transmitted across borders. Finally, the composition of international capital flows underlines the concept of "global liquidity", which plays a central role in the international monetary system (CGFS, 2011). For all these reasons, close monitoring of international financial flows is essential to assess the state of the global economic environment.

In recent years, international capital flows have registered profound changes, not only in terms of their magnitude but also their geographical patterns and composition by types of flows: bank flows, foreign direct investment (FDI), and portfolio (debt and equity) flows. At this stage, the explanatory factors and implications of these changing patterns are not clear; they will likely trigger a debate in academic and policy circles alike. This policy brief aims to contribute to this debate by presenting key stylized facts on international financial flows. We focus mostly on gross rather than net flows, which tend to be more commonly analyzed, but we also present a short analysis of the latter. We outline likely explanatory factors for these developments and sketch out their implications, based on existing research.

The objective here is primarily to get the facts right, but this proves somewhat challenging, as international financial flows are subject to measurement problems. Reconciling stock and flow measures is a further challenge. For this reason, we cross-check the information provided by different sources and report differences when they are substantial. The bulk of the analysis relies on the IMF Balance of Payments database, which reports data at a quarterly frequency. We complemented this with specific data sources for some countries, such as the BIS Locational Banking Statistics and the TICS data for the US, which provide a wealth of information on the world's largest economy. We also report data from EPFR, which show much larger retrenchments in the recent period, and discuss these data in a Box $\mathrm{C}$. We narrowed down the analysis to 40 countries, which represent more than $90 \%$ of world GDP. In the appendix we report the full data for $\mathrm{G} 20$ countries, owing to their systemic relevance. Our focus is on recent evolutions (2012Q1-2014Q4). We compare current trends with the precrisis period. ${ }^{2}$ The global financial crisis and its immediate aftermath have already been analyzed extensively elsewhere (in particular by Milesi-Ferretti and Tille, 2011). For this, we develop "retrenchment ratios" and report them for all countries and for all available sectors (FDI, portfolio equity, portfolio debt, and "other investments"). We also use longer-run statistics for aggregate data to get a historical perspective, and we comment on shorter-run dynamics when they are particularly interesting. Overall, four key stylized facts emerge from the exercise.

First, gross international capital flows appear to be historically weak and have not recovered from the "Great Retrenchment" (Milesi-Ferretti and Tille, 2011) observed in the wake of the global financial crisis. This is true in absolute value (when flows are measured in US dollars) but also when expressed as a percentage of global GDP. The weakness of international financial flows, therefore, not only reflects the sluggishness of the world economy; it goes beyond this, in a way reminiscent of the recent "global trade slowdown" (Hoekman, 2015). ${ }^{3}$ This evolution is puzzling as it could mean, if it persists, that the global economy is becoming more fragmented than it used to be, after decades of increasing globalization. Although one could indeed expect a correction from the levels observed in the period immediately preceding the global financial crisis, the level of inflows is low even if one takes a longer-term perspective, particularly for advanced economies.

The second stylized fact is that the weakness of international financial flows seems to affect all economic regions, albeit to a different extent. We provide in this note a battery of indicators that help monitor the evolution of international flows. Our "retrenchment ratios" report the change in in- and outflows for all 40 countries (and eight regions and country groupings), in absolute terms and in percentage of GDP. They are expressed as the difference between the value of these flows in the precrisis period (2005Q1-2007Q2) and the post-crisis period (2012Q1-2014Q4). Our summary tables also provide the decomposition by type of flows (see below). When looking at the balance of payments data, the fall is very broad-based across countries, but it is more pronounced for advanced than for emerging market countries. Among advanced economies, the current level of inflows is back to the level that was registered

(2) We define the pre-crisis period as 2005Q1-2007Q2 (2005 is the first yea of the new IMF BPM6 database). Taking this period as benchmark should not be interpreted in a normative way, especially given that this period was likely characterized by exceptional buoyancy of capital flows.

(3) International trade flows appear very weak compared to pre-crisis levels, which in itself is not very surprising given that economic activity is also les robust. More strikingly, global trade, which used to increase at twice the pace of global GDP, is now growing at roughly the same pace, suggesting that the relation between trade and GDP has changed, owing to a combination of cyclical and structural factors, as outlined in Hoekman (2015). 
in the mid-1990s. Among emerging market economies (EMEs), the fall is comparatively smaller, partly because the rise recorded in the decade preceding the global financial crisis was smaller (which in turn could be related to the crises that affected EMEs in the 1990s, to the lower level of financial development, overall, and to less open capital accounts). Euro area countries, especially those in the so-called periphery, recorded significantly lower flows as a percentage of GDP. This is consistent with the fact that the recovery was slower in advanced economies, particularly in Europe, compared to EMEs. A sectoral decomposition reveals that the fall in financial flows to and from Europe was particularly substantial for bank flows, which can be related to the fact that the European crisis markedly affected the banking sector. There are important differences between these balance of payment data and the type of portfolio inflows reported, e.g. in the EPFR database (the latter shows massive declines in inflows to EMEs over the recent period): these differences are analyzed in the last section below, especially in Box C.

Third, the global patterns of net flows have also recorded significant changes. Overall, net flows have fallen substantially, mirroring to a large extent current account changes. In the United States, net inflows are currently about half what they were before the crisis, in line with the reduction of the current account deficit. In Japan, net flows have switched from substantial net outflows to net inflows in the years following the crisis. Canada has also switched from net outflows to net inflows, but this change happened earlier, in the course of 2008. For Germany, by contrast, net outflows are larger, if anything, reflecting a growing current account surplus. Among EMEs, several countries now record lower inflows, such as Argentina, South Africa, Russia and South Korea (these last two countries actually record net outflows in the recent observations). We relate these changing patterns in net flows to changing patterns in gross flows for selected economies, and show in Chart Appendix 2 net inflows for all G20 countries (as for gross flows). This note also briefly mentions the reduction in global imbalances and the main factors that may explain it.

Fourth, while all types of flows have been affected by the slowdown, some have been significantly more resilient than others, resulting in a marked change in the composition of financial flows. Specifically, foreign direct investment (FDI) flows have fallen relatively less than other types of flows, while bank flows have plummeted (even turning negative ${ }^{4}$ ). Portfolio flows

(4) We consider here gross outflows (i.e. net purchases of foreign assets by domestic residents), and gross inflows (i.e. net purchases of domestic assets by foreign residents). As a result, both gross flows may become negative. For instance, if foreign residents sell domestic assets massively, this will result in negative gross inflows. are in the middle, and within this category, debt instruments have fallen much more than equities. As a result of these changes, the composition of international financial flows is now drastically different. Whereas the "other investment" category (mostly bank flows) used to account for more than $40 \%$ of total flows before the crisis, these flows now constitute a small share of the total. By contrast, the share of FDI has roughly doubled, from $24 \%$ to $45 \%$. Within the portfolio category, the different paths described above have also led to a considerable reallocation: before the crisis, portfolio debt used to be more than twice the size of equity flows, whereas they are now of roughly equal magnitudes.

Building on existing research, several factors can be put forward regarding the likely causes of these evolutions. Bank flows may have been more strongly affected than other types of flows because of the problems that plagued the banking sector in advanced economies and led them to undertake a deleveraging process. As is well documented by now, the interbank market froze in the wake of the financial crisis, which affected cross-border lending by banks to other financial institutions. The changing composition of international financial flows may, therefore, reflect the disintermediation process that characterizes the global economy. Importantly, local lending by foreign bank affiliates may now substitute cross-border lending (IMF GFSR, 2015). In addition, the "Great Trade Collapse" (Baldwin, 2009) and ensuing "trade slowdown" (Hoekman, 2015) may have contributed to the weakness of bank flows to the extent that trade and financial flows are complementary (Coeurdacier and Aviat (2007)). ${ }^{5}$

These trends also have implications for financial stability issues. In particular, a stream of the literature has highlighted that the different types of flows typically exhibit different volatilities and do not show the same level of resilience during crises. $^{6}$ One can note that these differences in the volatility of financial flows have been reflected in their respective evolutions since the crisis: noticeably, FDI flows proved more resilient than portfolio and especially banking flows. However, it is still an open question whether the volatility patterns observed previously will prevail in the "New Normal".

(5) Based on simultaneous gravity equations for bilateral trade in goods and asset holdings, and using instruments for both variables, they find that a 10\% increase in bilateral trade raises bilateral asset holdings by $6 \%$ to $7 \%$. They also find that causality in the other direction is significant, but smaller in magnitude. (6) Conventional wisdom states that FDI flows represent a more stable source of balance of payment financing compared to portfolio and bank flows (in addition to other benefits, including the technology transfers they may entail); see e.g. Levchenko and Mauro (2007) or Albuquerque (2003). However, the extent to which they are indeed more stable is debated; see, for instance, Brukoff and Rother (2007), Bluedorn et al. (2013) and the references cited therein. The relative stability of different types of capital flows has crucial implications for capital account openness and in particular its sequencing (see e.g. Kaminsky and Schmukler, 2003, or Bussière and Fratzscher, 2008). 
This policy brief relates to existing studies that explored the recent evolution of international financial flows. MilesiFerretti and Tille (2011) provided an early analysis of the "Great Retrenchment" in international capital flows. They noted, in particular, that bank flows were hit the hardest, and that the retrenchment was shorter-lived for emerging economies. This policy brief shows that this retrenchment continued and even amplified beyond the early stage of the crisis. Bluedorn et al. (2013) have assembled a large database covering 147 countries since 1980 at an annual frequency and 58 countries at a quarterly frequency. They document and highlight the high volatility of international capital flows, with FDI flows being comparatively less volatile than bank and portfolio flows (but these last two types of flows are not fundamentally different in terms of volatility). While they do not find significant differences across country groups - advanced economies (AEs) versus emerging markets EMs - regarding the volatility of gross flows, they note that AEs "experience greater substitutability across the various types of net flows and greater complementarity of gross inflows and outflows". Our policy brief also relates to a large strand of the literature that sought to identify the determinants of international capital flows, including Broner et al. (2013), Forbes and Warnock (2012), Fratzscher (2012), Ghosh et al. (2014), Puy (2015), Erce and Riera-Crichton $(2015)^{7}$ and especially the papers that focus on the determinants of bank flows (see e.g. Buch and Goldberg, 2015, and the literature reviewed therein). By focusing on gross and not just net flows, we hope to contribute to the analysis put forward by Obstfeld (2012), who emphasizes the role of gross flows. Importantly, however, we focus here predominantly on international capital flows and not stocks (i.e. the international investment position, in net and gross terms). This is not to say that stocks do not matter, as clearly they do, but flows provide an early evaluation of where stocks are going and catch substantial attention in themselves. The present paper also echoes the analysis of Borio and Disyatat (2015), who emphasize the importance of financing in the analysis of the external sector. Our policy brief complements recent contributions that focused on the vulnerability of EMEs to sudden stops of capital flows, and analyzed the role of gross flows separately, aiming to distinguish the impact of inflows from that of outflows (see e.g. Alberola et al., 2015, and the references therein). Finally, while we do not aim to evaluate the impact of capital flows on growth, our policy brief relates to the strand of the literature that looked at the short- and long-run effects of capital flows on growth (see, for instance, Blanchard et al. 2015, Bussière et al. 2015, Reinhart and Reinhart, 2009 and the references cited in these papers). We hope that the stylized facts presented here will feed into this debate. ${ }^{8}$

(7) These papers take mostly an empirical approach; see Tille and Van Wincoop (2010) for a theoretical view.

(8) We do not consider, in this short policy brief, the effect of capital controls and other tools aimed at managing international capital flows. Interested readers may check IMF (2012), Ostry et al. (2011, 2012), Pasricha et al. (2015), Forbes et al. (2015), as well as the references therein.
The rest of the note is organized as follows. Section 2 focuses on total gross flows (lumping together portfolio, FDI and other investments) for the world as a whole and for the world's largest countries and regions. Section 3 turns to the composition of financial flows. It outlines some of the possible factors that may explain why some components have been more resilient than others, and suggests the likely implications, for the global economy, of the new composition of financial flows. A chart appendix reports the flows (both inflows, outflows, and net flows), distinguishing also across types of flows, for G20 countries. A table appendix provides complementary information on the countries ${ }^{9}$ included in our sample.

\section{Global financial flows: dwindling to a trickle}

\subsection{The rise and fall of global financial flows}

The decade preceding the crisis has been one of financial globalization. The ramping-up of international capital flows and the accumulation of external assets and liabilities in the decades preceding the global financial crisis were perhaps even more dramatic than the already impressive acceleration of trade flows and the development of current account imbalances that took place over this period. This can be related to greater capital account openness (see Chart 1, based on the ChinnIto (2006) index; see also Quinn, Schindler and Toyoda, 2011, who present a larger set of indicators). Overall, the magnitude of gross inflows in advanced and emerging countries rose markedly up to the 2008-09 global financial crisis, especially for the former (Chart 2). Comparing the current period with the period immediately before the global financial crisis may be biased, as capital flows were historically high, especially for AEs (for EMs the rise was less pronounced and the level was lower, partly because of the crises that plagued EMEs in the 1990s and early 2000s). However, even if one takes a longer perspective, capital flows appear low, especially among AEs, where they are back to their mid-1990s level.

When financial globalization matured before the onset of the crisis in 2008, orders of magnitude had changed relative to a decade earlier (Milesi-Ferretti and Tille, 2011):

- Foreign assets constituted a significantly bigger share of portfolios; the value of those assets also rose relative to GDP generally (financial deepening, valuation effect).

- Financial globalization had been more pronounced in AEs than EMs, the former receiving more gross inflows than the latter (chart 2).

(9) Although the appendix lists the euro area as a separate economy (thus abstracting from intra-euro area flows), the aggregate flows reported in sections 2 and 3 below are based on individual euro-area countries, thus taking into account intra-euro area flows. 
Chart 1 - Capital account openness is receding since the crisis after decades of liberalization

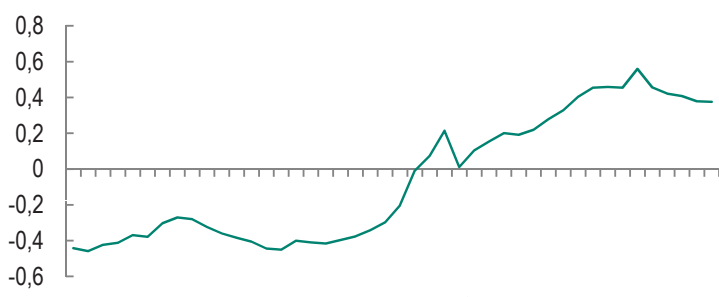

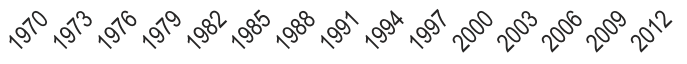

Source: Chinn-Ito index, retrieved online at http://web.pdx.edu/ ito/Chinn-Ito_website. $\mathrm{htm}$. Unweighted average of the de jure capital account openness as defined in Chinn and lto (2006).

Chart 2 - The boom of gross inflows in advanced and emerging market economies...until the crisis.

$(\% \mathrm{GDP})$

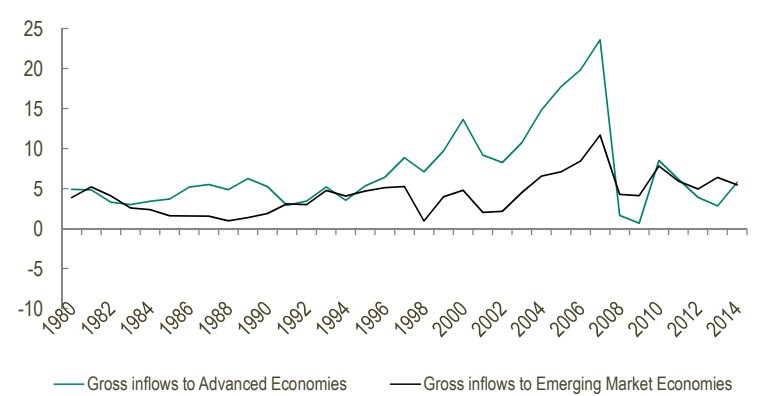

Source: Bluedorn et al. (2013)

- The size of current account imbalances and of creditor/debtor positions had become more dispersed (Bracke et al., 2008).

- The banking sector in AEs had been one of the key drivers of financial globalization. Banks extended their international activities during the globalization process, either through plain cross-border lending or via foreign affiliates, which played an important role in the subsequent period (see Cetorelli and Goldberg, 2011, 2012, and the references therein).

\section{8 and beyond: marked financial retrenchment relative to pre-2008 dynamics}

With this pre-2008 snapshot in mind, this section offers a bird's eye review of major stylized facts that emerged since 2008 . We document international financial interdependencies by focusing on gross quarterly capital flows - outflows and inflows - since 2005. We deliberately choose to remain mainly at an aggregate level of description in this section, allowing only for a geographical split between AEs and EMs. Section 3 will dig deeper into sectoral categories of capital flows, breaking down aggregates into foreign direct investment (FDI), portfolio investment and other investment (which we use as a proxy to bank flows; see discussion in Box A), while also cross-checking different sources of data. Based on balance of payments data as of the last quarter of 2015 , three key stylized facts emerge.
Stylized fact No. 1: The "Great Retrenchment" of gross international financial flows seems fairly persistent

In the years preceding 2008, gross international financial flows were very substantial, hovering around a quarterly aggregate of around $10-15 \%$ of global GDP. That was equivalent, back then, to about USD 2,000 bn. The onset of the financial crisis in the summer of 2007 put a "sudden stop" to that flourishing regime: in the first quarter of 2008, these flows were suddenly reduced to nil (Chart 3). ${ }^{10}$ Then came the Lehman event, when the bank collapsed in the third quarter of 2008. This is when aggregate gross flows massively retrenched, as visible in Chart 3. In that quarter alone, their reversal was equivalent to $-10 \%$ of global GDP.

Chart 3 - Post crisis, global gross financial flows settled at a lower level

(quarterly data)

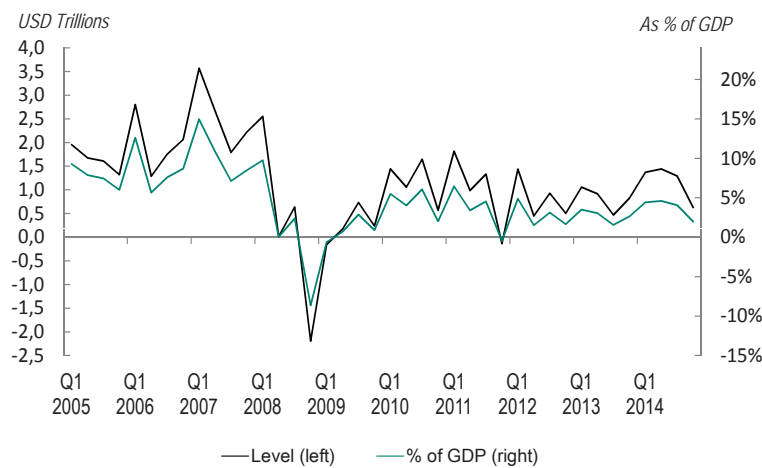

Source: IMF Balance of Payments (BoP) statistics and authors' calculations.

Since 2010, gross cross-border financial flows have not returned to the buoyancy of the pre-crisis period. Instead, as of the end of 2014, they seemed to have settled at a "new average" that looks to be below $5 \%$ of GDP (Chart 3). This muted revival raises questions about whether the pre-crisis intensification of global financial linkages, summarized above, was too exuberant.

\subsection{The geographical pattern of global financial flows: stylized facts}

\section{Stylized fact No. 2: The retrenchment applies mainly to advanced economies}

The retrenchment of global financial flows after the 2008 sudden stop turns out to be predominantly an advanced economy story. In fact, a sharp contrast between advanced and emerging economies emerged after the sudden stop in 2008. Then, flows to and from advanced countries seemed to have stabilized around an average that was significantly lower than what prevailed before 2008 (Chart 4).

(10) In this section and in the rest of the paper (except where otherwise indicated), we use quarterly data from the IMF BoP statistics, which start in 2005. 
By contrast, no such downscaling of flows happened in emerging economies taken as an aggregate, where the sudden stop seems to have been temporary (Chart 4). The apparent resilience of emerging markets contrasts with the widespread perception - underpinned by specific data sources such as the EPFR database - that these countries suffered from a structural retrenchment of investors (there is also a timing issue as the data reported here stop at the end of 2014). Volatility in capital outflows may have been exacerbated by developments in US monetary policy, in particular as US treasury yields surged in the summer of 2013 when the Federal

Reserve hinted at a forthcoming winding-down of its asset purchases (this episode is now referred to as the "Taper Tantrum", in relation to the tapering-off of quantitative easing), or as the Federal Reserve actually started to tighten interest rates at the end of 2015. But quarterly balance of payment data suggest that, looking through the shorter-term volatility of flows, investment into emerging markets has in fact proved resilient. We provide details on the data comparability with EPFR sources in Box C.

While emerging economies fared much better than the advanced countries after the global financial crisis, the latter account for a much larger share of total flows than emerging markets (the ratio is about 1 to 10$)^{11}$. As a result, the fall recorded by the former could not be offset by the recovery of the latter, and global flows are now smaller than they were before the crisis.

In emerging markets, gross capital flows were significantly more resilient than in advanced economies already in the early phase of the crisis (Chart 4). After 2008, capital inflows into EMs recovered quickly and even outpaced pre-crisis levels, although the most recent numbers show a downward trend. This is likely related to the underlying drivers of these inflows, namely monetary policy in industrialized countries, in particular the

US. While liquidity abundance in AEs pushed investors towards EMs, this trend has dwindled lately as signals of monetary policy normalization became more apparent. Looking at capital outflows more closely (left-hand side panel) suggests that capital outflows from emerging countries have been more resilient than those originating from advanced economies. Within the block of emerging countries, this resilience in international exposure of investors holds less true in Eastern Europe, as shown in the regional breakdown of flows (Chart 5). The most plausible explanation of the fact that Eastern Europe remains the hardesthit when it comes to emerging countries is its close relationship with Western Europe, in particular via balance-sheet exposures - in particular of the banking sector - that go in both directions.

(11) The difference partly reflects the fact that several advanced economies, like the UK and Luxembourg, are financial hubs, such that flows to and from these centers are hard to attribute to specific countries.
Another factor could be the exchange rate for some countries, again via balance-sheet vulnerabilities related to the currency mismatch between the assets and liabilities not only of the financial sector but also households and firms. Finally, contrary to the general shrinkage that emerges from the world picture, Asia and Latin-America generally recorded a rise in their outflows (Chart 5). Likewise, they became more dependent on external funding by a substantial amount, with rising inflows (see Table Appendix 1 and 2).

We now look beyond aggregate facts and investigate countrylevel developments. To that purpose, we developed a simple metric, which we call a "retrenchment index". This index compares the level at which capital flows settled after the 2008 sudden stop (since the first quarter of 2012) with their precrisis average over the period 2005Q1 to 2007Q2. We use both a retrenchment index in absolute value (Table 1 presents the top and bottom 10 countries, Table Appendix 1 reports data for the whole sample) and one in relative terms, dividing the absolute difference by GDP in the first period (see Table 2, and Table Appendix 2 for the full sample). The first indicator is informative about the magnitudes at play and about which countries contributed most to the global retrenchment, but it puts more weight on large countries and therefore blurs the comparison across countries, which is why we complemented it with the second indicator. We thus obtain a clear picture. First, capital flows indeed intensified in the BRICs and in some "safe havens" such as Luxembourg and Singapore. As a matter of fact, the intensification of inflows to Luxembourg suggests that "financial centers" have continued to cater for the redistribution of flows across countries. Second, by contrast, the retrenchment of capital flows turns out to be the most severe in western European countries, including the UK, peripheral EMU countries and France. Research focusing on EMU countries pointed out the large flows that characterized EMU countries prior to the crisis (see e.g. Hale and Obstfeld, 2014).

\subsection{Global patterns in net flows}

Turning now to the global patterns of net flows, significant changes have also been recorded since the crisis. Overall, net flows have fallen significantly, mirroring to a large extent the changes registered in the current account. ${ }^{12}$ This decrease in net flows, in absolute value, as reported already in Bluedorn et al. (2013), is consistent with the fact that global current account positions have also fallen in absolute value (see the last chart of Chart

(12) The financial and current accounts should in principle match each other; in practice they do not, because the changes in international reserves should be taken into account, and because of sometimes large net errors and omissions. 
Chart 4 - Gross capital outflows and inflows for emerging and advanced economies

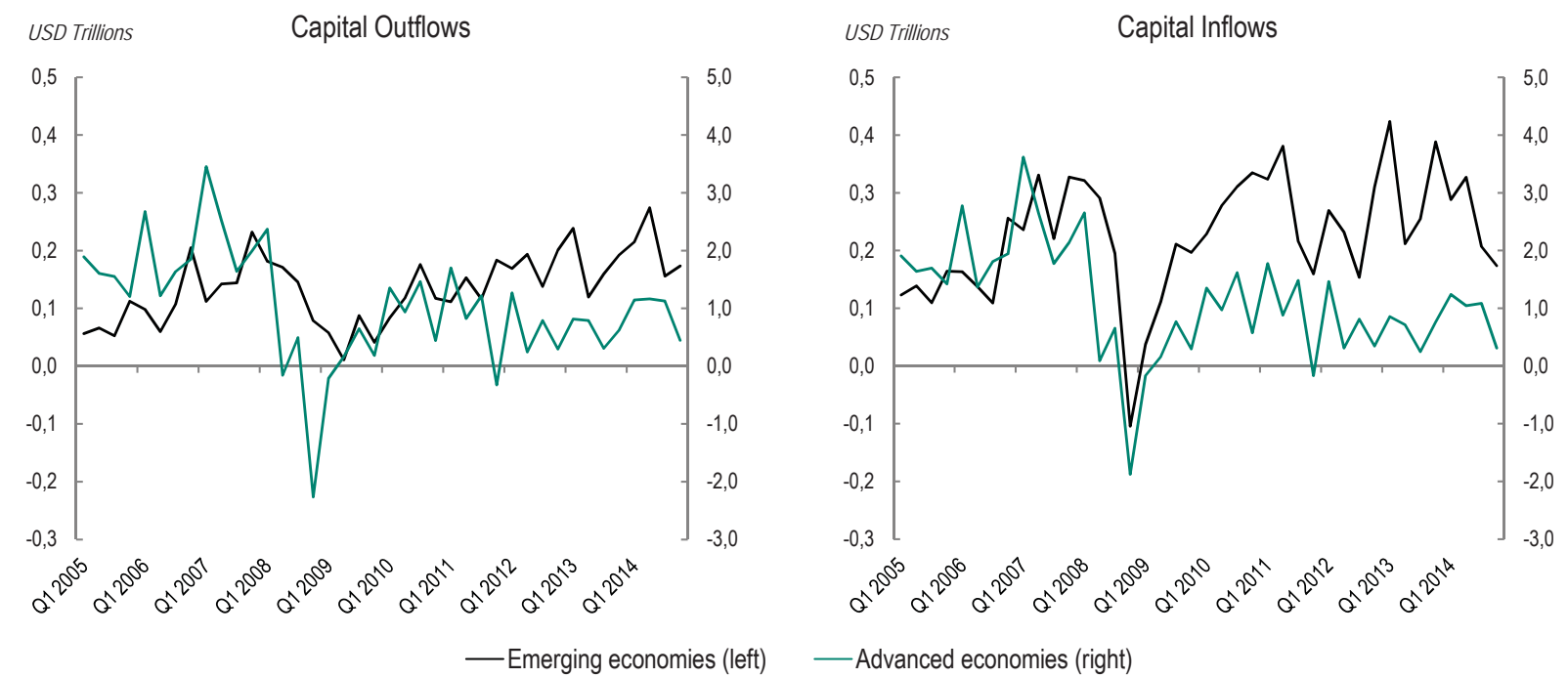

Source: IMF Balance of Payments (BoP) statistics and authors' calculations.

Chart 5 - The persistent adjustment of capital flows is also geographically differentiated

Emerging economies: Capital Outflows by area
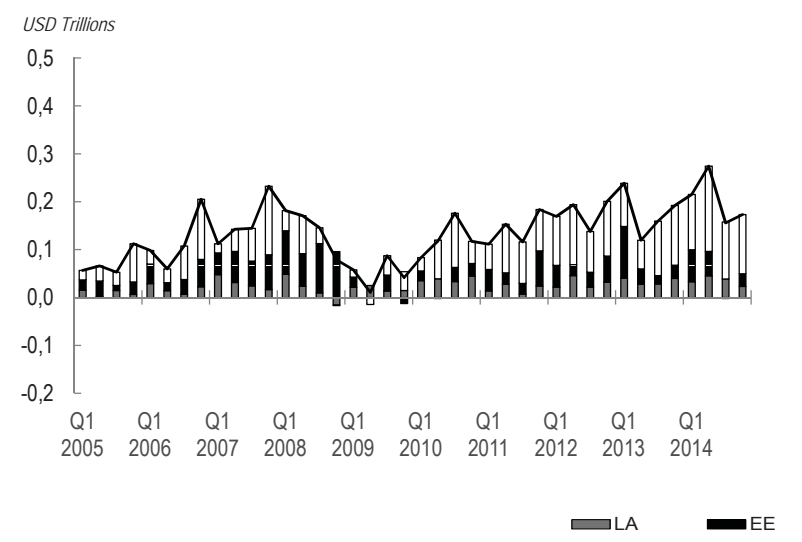

Advanced economies: Capital Outflows by area

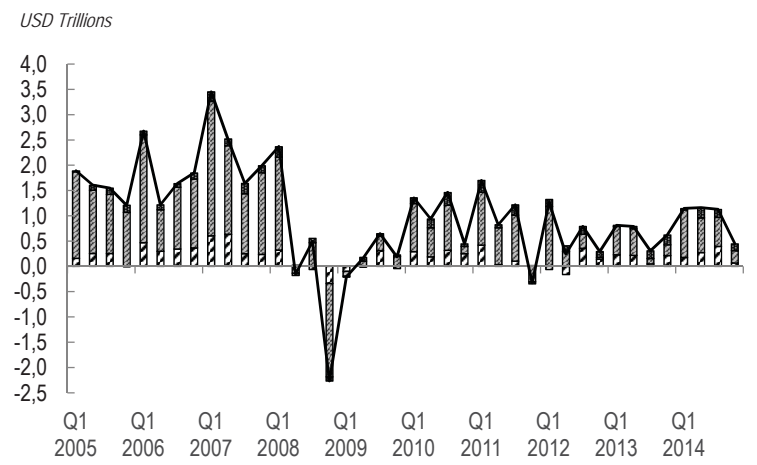

Emerging economies: Capital Inflows by area

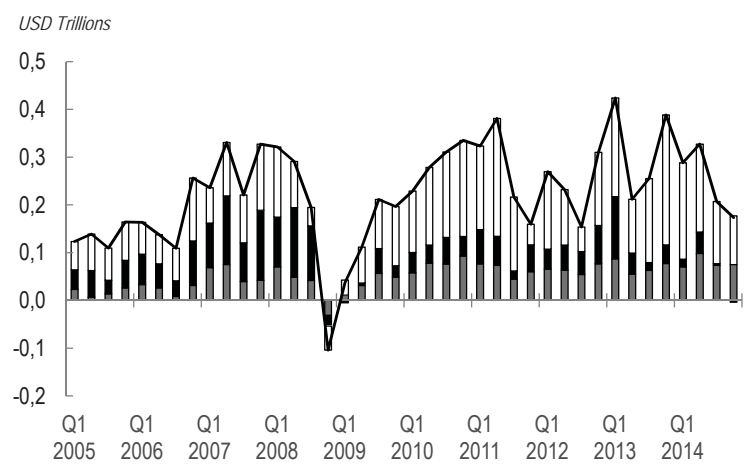

$\square \mathrm{EmA}-$ Total

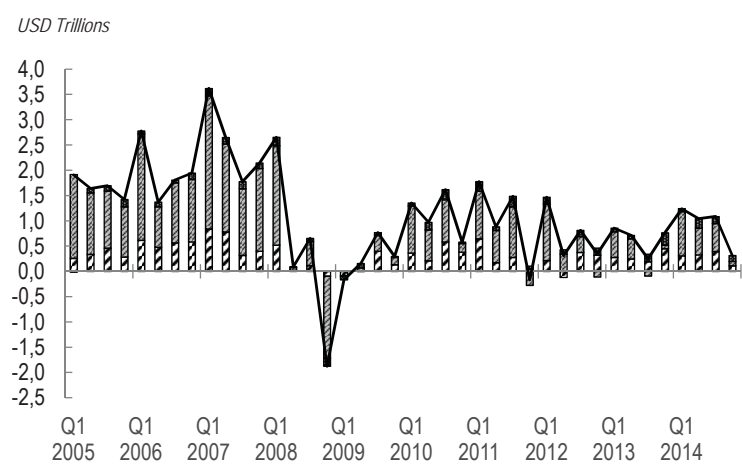

ITANA Total 
Table 1 - Retrenchment indicators, in absolute terms (USD bn), top and bottom 10 countries

(Top and bottom 10 countries ranked by size of absolute difference between post and pre-crisis outflows and inflows)

\begin{tabular}{llrllr}
\hline & & Outflows & & & Inflows \\
\hline LX & Luxembourg & 309,9 & LX & Luxembourg & 311,5 \\
CH & China & 203,1 & CH & China & 220,9 \\
RS & Russia & 62,4 & JP & Japan & 143,7 \\
KO & South Korea & 35,7 & BR & Brazil & 84,6 \\
BR & Brazil & 33,2 & MX & Mexico & 55,1 \\
TW & Taiwan & 27,7 & IN & India & 46,2 \\
IN & India & 12,1 & CA & Canada & 42,6 \\
TH & Thailand & 11,5 & ID & Indonesia & 34,7 \\
AU & Australia & 10,9 & AU & Australia & 31,4 \\
CL & Chile & 10,0 & CL & Chile & 21,9 \\
\hline ES & Spain & $-190,4$ & AT & Austria & $-152,8$ \\
BG & Belgium & $-203,8$ & BG & Belgium & $-196,1$ \\
SW & Switzerland & $-204,2$ & IT & Italy & $-258,5$ \\
IT & Italy & $-211,2$ & IR & Ireland & $-292,6$ \\
IR & Ireland & $-293,7$ & ES & Spain & $-312,3$ \\
DE & Germany & $-371,4$ & DE & Germany & $-443,1$ \\
NL & Netherlands & $-440,8$ & NL & Netherlands & $-485,5$ \\
FR & France & $-591,0$ & FR & France & $-596,4$ \\
US & United States & $-690,9$ & US & United States & $-1086,9$ \\
UK & United Kingdom & $-1609,0$ & UK & United Kingdom & $-1528,6$ \\
\hline
\end{tabular}

Source: Authors calculations on the basis of IMF balance of payments data. Note: Periods: Pre-crisis: 2005Q1 - 2007Q2, Post-crisis: 2012Q1 - 2014 Q4.

Table 2 - Retrenchment indicators, as a percentage of GDP, top and bottom 10 countries

(Top and bottom 10 countries ranked by size of difference between post and pre-crisis outflows and inflows, \% of GDP)

\begin{tabular}{llrllr}
\hline & Outflows & & & Inflows \\
\hline LX & Luxembourg & 134,6 & LX & Luxembourg & 135,3 \\
CH & China & 8,1 & CL & Chile & 15,1 \\
TW & Taiwan & 7,2 & ID & Indonesia & 10,1 \\
CL & Chile & 6,9 & CH & China & 8,8 \\
RS & Russia & 6,7 & BR & Brazil & 8,0 \\
TH & Thailand & 5,4 & IN & India & 5,1 \\
KO & South Korea & 3,7 & AU & Australia & 4,0 \\
NZ & New Zealand & 3,3 & CA & Canada & 3,4 \\
BR & Brazil & 3,1 & JP & Japan & 3,3 \\
ID & Indonesia & 1,6 & TH & Thailand & 1,8 \\
\hline ES & Spain & $-15,2$ & DK & Denmark & $-21,0$ \\
FN & Finland & $-15,8$ & ES & Spain & $-24,9$ \\
NW & Norway & $-16,2$ & FR & France & $-25,7$ \\
FR & France & $-25,4$ & PT & Portugal & $-26,0$ \\
AT & Austria & $-45,7$ & SW & Switzerland & $-32,6$ \\
SW & Switzerland & $-47,9$ & AT & Austria & $-46,0$ \\
BG & Belgium & $-49,7$ & BG & Belgium & $-47,9$ \\
NL & Netherlands & $-60,9$ & UK & United Kingdom & $-59,2$ \\
UK & United Kingdom & $-62,3$ & NL & Netherlands & $-67,0$ \\
IR & Ireland & $-127,5$ & IR & Ireland & $-127,1$ \\
\hline
\end{tabular}

Source: Authors calculations on the basis of IMF balance of payments data.

Appendix 2). Chart 6 reports net flows as a percentage of GDP for selected economies, while Chart Appendix 2 reports these data for all G20 countries ${ }^{13}$.

In the United States, net inflows expressed as a percentage of GDP have decreased by about $50 \%$ when the pre- and post-crisis periods are compared, in line with the reduction of the current account deficit over the same period (the US current account deficit peaked at $5 \%$ of GDP in 2007 and has fluctuated at around $2.5 \%$ in recent years). The decomposition of net flows into gross inflows and outflows reveals that the falling magnitude of net inflows is mostly due to lower gross inflows in the US (net purchases of US assets by non-residents), rather than higher gross outflows (net purchases of foreign assets by US residents). To anticipate the

(13) We omitted Saudi Arabia for data availability reasons. discussion in Section 3 (which decomposes flows by types), lower gross inflows in the United States are mostly due to portfolio debt and to the "other investment" category, which includes bank credit. Another interesting example in this respect is Japan, where net flows have switched from substantial net outflows before the crisis to net inflows in the years following it: this should not be surprising, since during the same period, Japan's trade surplus has turned into a deficit, significantly reducing the size of the current account surplus (in 2007 Japan's current account surplus represented $4.9 \%$ of GDP whereas in 2014 it reached only $0.5 \%$ ). Canada has also switched from net outflows to net inflows, but this change happened earlier, in the course of 2008. Canada's current account surplus ( $0.8 \%$ of GDP in 2007) basically vanished in 2008 and turned into a substantial deficit thereafter (-2.1\% in 2014 and approaching $-3 \%$ in 2015). In the case of Canada, the switch to net 
inflows can be mostly related to higher gross outflows, especially in the category "portfolio debt". For Germany, by contrast, net outflows have become larger, if anything, reflecting a large (and growing) current account surplus: it amounted to $6.7 \%$ of GDP in 2007 and has remained well above $6 \%$ in recent years, reaching $7.4 \%$ in 2014). The decomposition between outflows and inflows reveals that it is especially the latter that fell.

Among EMEs, several countries now record lower net inflows, such as Argentina, South Africa, Russia and South Korea (these last two countries actually record net outflows in the recent observations). In the case of South Korea, it is mostly growing purchases of foreign assets by domestic residents that can explain the change in the net position. In recent years, South Korea's current account balance has recorded increasing surpluses $6.3 \%$ in 2014, from close to balance in 2008). By contrast, Brazil, Indonesia and Mexico seem to record still sizable net inflows, or even higher net inflows overall. In all three cases, higher net inflows largely result from foreign residents buying more domestic assets over time: FDI mostly in the case of Brazil and Indonesia, portfolio flows in the case of Mexico. Over the same period, all three countries recorded deficits. Brazil's current account, which was roughly balanced in 2007 , turned into a deficit soon after, which grew over time, to reach $4.4 \%$ in 2014 . Indonesia's current account balance moved from a surplus in the late 2000s to a deficit in the first part of the 2010s. Mexico's deficit was below 1\% of GDP in 2009-10 but rose thereafter, to about 2\% in 2014. For India and Turkey, net inflows rose but then abated somewhat recently (in line with the fact that India's current account deficit, which reached $4.8 \%$ of deficit in 2012 , fell subsequently, to $1.3 \%$ in 2014 , while Turkey's current account deficit also decreased in 2014, albeit at a high level: 5.8\% of GDP in 2014).

In turn, the reduction of global imbalances, as shown in Chart Appendix 2, can be related to a number of factors. The fall in oil prices reduced both net oil imports for oil-importing countries and net oil exports for oil-exporting countries, with sizeable effects on global imbalances (in 2007, the surpluses of oil-exporting countries combined were the largest contributors to global surpluses). Meanwhile, the progressive evolution of China's growth model away from an export-led economy to stronger domestic sources of growth has led to a noticeable reduction in the supply of traded goods (Gaulier et al., 2014). In parallel, lower aggregate demand in advanced economies, particularly in the import intensive categories of expenditures such as business investment, has affected real imports from AEs significantly (Boz et al., 2014). All these factors have contributed to the reduction of global imbalances, which correspond to lower flows in the financial account.

Chart 6 - Net financial flows, selected economies

United-States

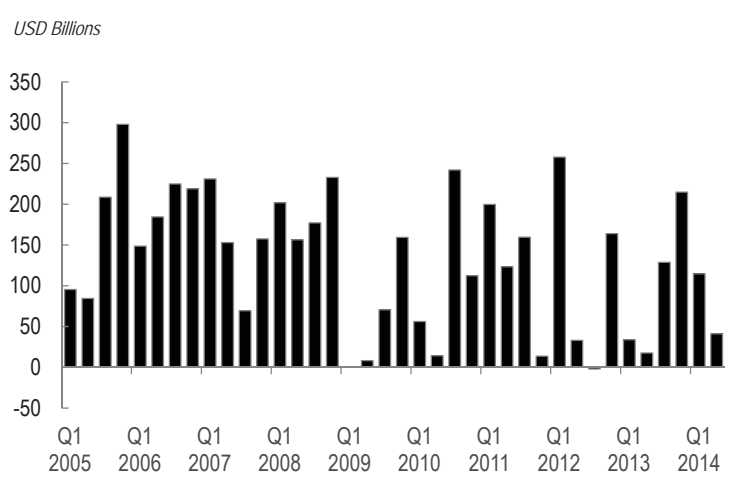

Mexico

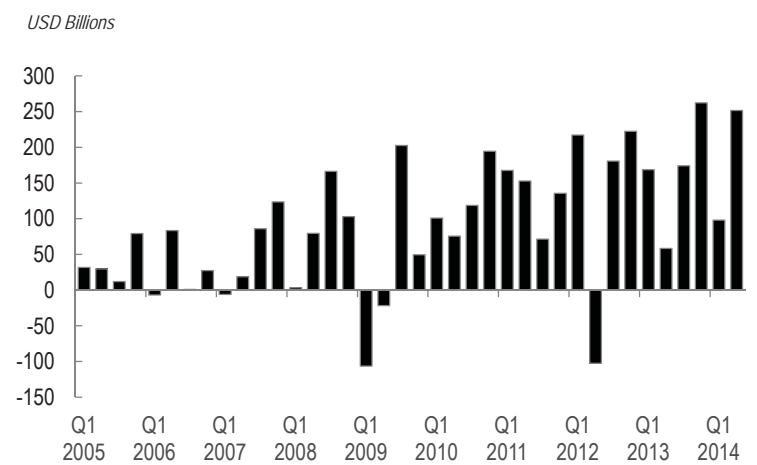

Japan

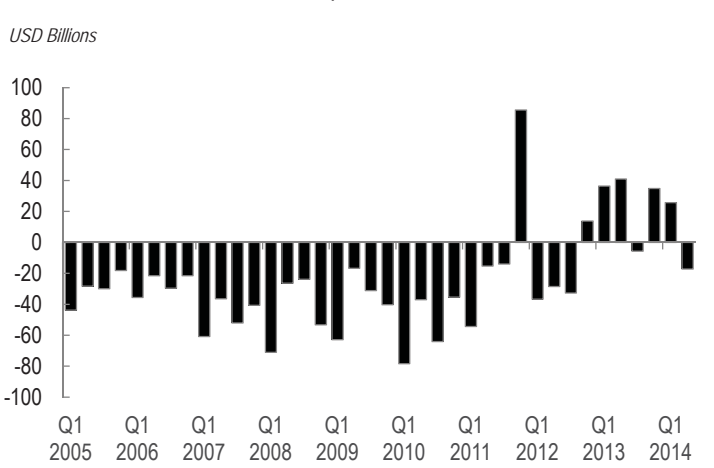

Source: IMF Balance of Payments (BoP) statistics and authors' calculations Note: A positive sign indicates net inflows. 
Factors of a more financial nature might have also played a role in taming net balances. In particular, we do not include transactions in foreign reserves in our measure of resident outflows. Yet, the accumulation of foreign reserves is a way for residents to accumulate savings abroad (Broner et al., 2013), so ignoring them may understate the accumulation of holdings abroad. In addition, well-known measurement issues around errors and omissions might interfere with our stylized facts (errors and omissions tend to be large during periods of turmoil and might reflect partly resident capital leaving a country without being reported).

\section{When the composition of capital flows matters}

\subsection{Different components, different degrees of resilience}

While the previous section focused on aggregate flows, we now turn to the decomposition by main categories, which reveals that the collapse of international financial flows has been very uneven (Chart 7). ${ }^{14}$ Strikingly, foreign direct investment (FDI) has been very resilient (flows in the post crisis period are just one notch below their pre-crisis level), whereas flows in the "other investment" category - which comprises bank flows have been almost completely wiped out. Portfolio flows come somewhat between these two extremes, but even there, significant heterogeneity prevails: portfolio equity flows have been much more resilient than debt flows, which have halved between the pre- and the post-crisis periods. The resilience of equity flows bodes well for the ability of the economy to withstand forthcoming shocks as it has better risk-sharing properties than debt (Albuquerque, 2003). One should underline, nonetheless, that there has not been a substitution between types of flows: all flows have fallen, but in different proportions.

As a result of these different evolutions, the composition of world flows is now fundamentally different from what it used to be before the crisis (Chart 8 ). In the pre-crisis period, the "other investment" category used to constitute the bulk of global flows, with a share of $44 \%$, whereas this share is now about $12 \%$. By contrast, whereas FDI used to represent less than a fourth of the total, in the post-crisis period FDI amounts to $45 \%$ of total flows. Finally, the share of portfolio investment has increased, from

(14) In this section we focus on the asset side of international portfolio flows. In principle, the data should match the data series on the liability side at the world level. However, due to statistical errors and since our database does not include all countries in the world, global assets and liabilities do not match exactly. In spite of these discrepancies, the data for global liabilities lead to the same conclusions, in terms of which flows have been the most resilient. Another challenge is that not all countries report the split between debt and equity in the "portfolio" category, or at least not since 2005. To provide a meaningful comparison, we have therefore split this chart (and the subsequent one) in two, showing first the broad "portfolio" category for the whole sample, and then the debt/equity split for the restricted sample of countries, losing in the process Argentina, China, India, Mexico and Turkey. We also omitted Saudi Arabia for data availability reasons related to the "other investment" account.
Chart 7 - The resilience of direct investment and equity flows contrasts with the contraction in bank flows and portfolio debt $(\%$ GDP)

Chart 7a: Breakdown between portfolio, FDI and other investment (full sample)

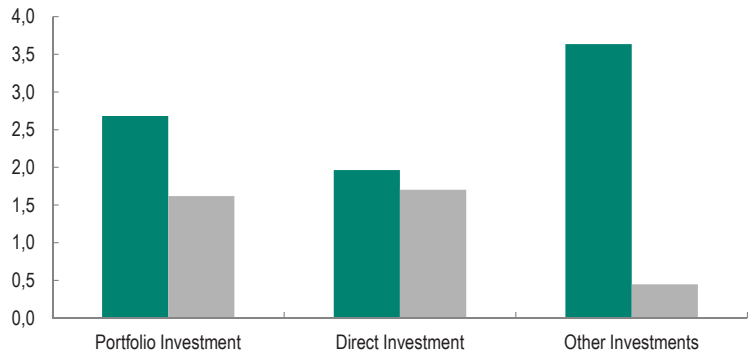

Chart 7b: Breakdown of the portfolio investment category between debt and equity (restricted sample of the countries reporting the debt and equity categories separately since 2005)

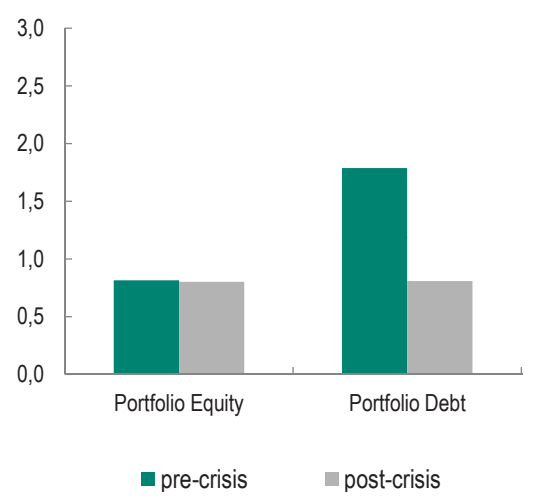

Source: IMF Balance of Payments (BoP) statistics and authors' calculations.

about one-third to more than half. Within the portfolio category, the share of debt has fallen, from two-thirds to about half compared to the share of equity, which has risen correspondingly (as shown in the lower panel of Chart 8).

Before turning to possible explanations for this dramatic change in the composition of global financial flows and its likely implications for the global economy, it is worth exploring the geographical breakdown of the flows.

To that aim, we construct "retrenchment ratios" that reflect the change in in- and outflows in absolute terms and in percentage of GDP. They are expressed as the difference between the value of these flows in the pre-crisis period (2005Q1-2007Q2) and the post-crisis period (2012Q1-2014Q4). Table 3 reports the ratio of the post-crisis flows divided by the pre-crisis flows for the main regions of the world, on the asset and on the liability sides. Several key findings stand out.

- First, the collapse of the "other investment" category can be predominantly attributed to advanced economies: the fall is particularly pronounced for Western Europe, and very noticeable for North America, for capital flowing both in and 
Chart 8 - Composition of global financial flows by categories before and after the crisis*

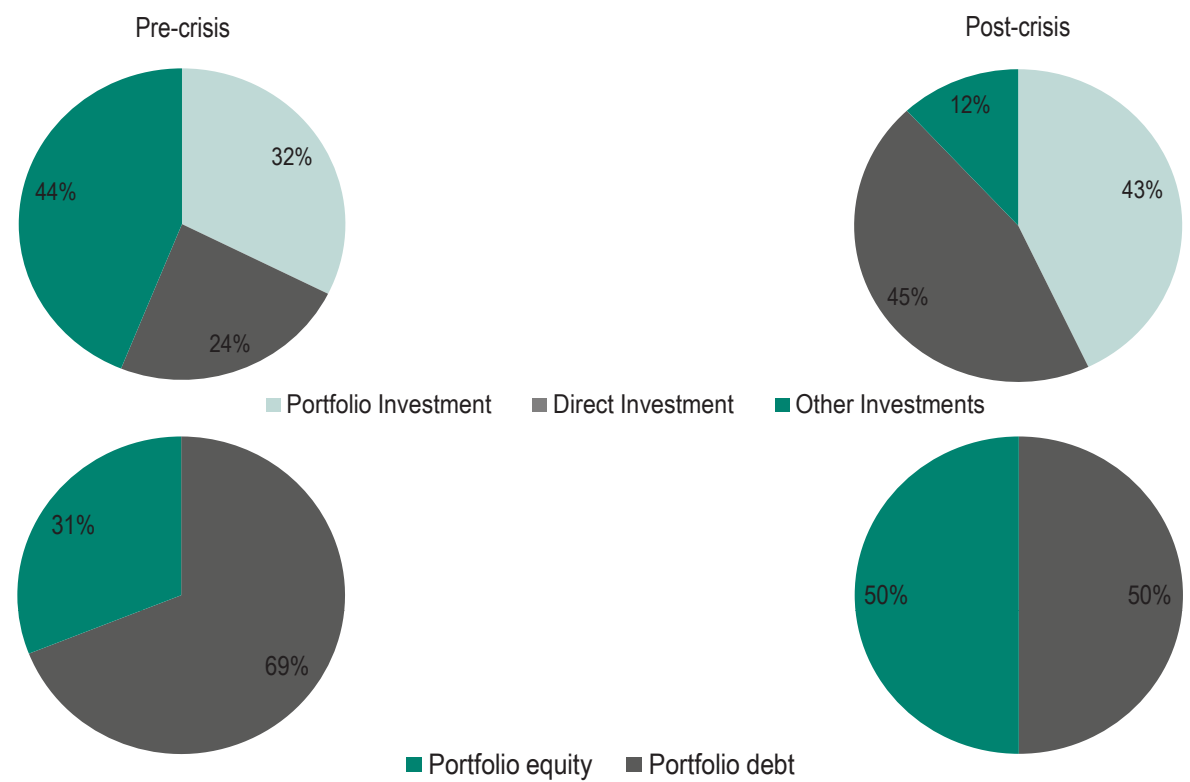

${ }^{*}$ As in the previous chart, Chart 9 shows two sets of charts corresponding to different sample composition. The upper panel reports data for the full sample for the broad categories FDI, portfolio and "other investment". The lower panel reports the composition of debt and equity within the "portfolio" category, for the restricted sample of countries reporting this split since 2005.

Source: IMF Balance of Payments (BoP) statistics and authors' calculations.

out. For Western Europe, the flows have been negative in the post-crisis period because assets and liabilities have been sold, resulting in negative gross flows. This is consistent with the fact that the European crisis affected the banking sector, and led to substantial deleveraging and disintermediation thereafter (which Section 3 will return to).

- For other regions, the evolution of this "other investment" category has been very different. In particular, in Asia flows in both directions have increased between the two periods. In Latin America, "other investments" have increased markedly on the "asset" side (this is particularly the case for Brazil; see Chart Appendix) and rose slightly on the "liability" side. For Eastern European countries, "other investments" have increased on the asset side but decreased significantly on the liability side. Overall, the collapse in other investment flows originating from and going to advanced countries (North America and especially Western Europe) was less than compensated by the rise recorded in other regions because the size of these regions in the pre-crisis flows was overwhelming for advanced countries (international financial flows are much larger for AEs than for EMEs).

- Turning to the other flows, one can note that FDI flows have been fairly resilient for most regions of the world; they even show an increase, on the asset side, for all regions except Western Europe. On the liability side also, FDI has increased between the two periods, except for Western Europe, North America, and Eastern Europe (in both cases a fall by $15 \%$ to $20 \%$ ).

Table 3 - Difference between sum of flows 2012Q1-2014Q4 and sum of flows 2005Q1-2007Q2 $(\% \mathrm{GDP})$

\begin{tabular}{|c|c|c|c|c|c|c|c|c|c|c|}
\hline & \multicolumn{5}{|c|}{ Outflows } & \multicolumn{5}{|c|}{ Inflows } \\
\hline & $\begin{array}{l}\text { Portfolio } \\
\text { Equity }\end{array}$ & $\begin{array}{l}\text { Portfolio } \\
\text { Debt }\end{array}$ & $\begin{array}{c}\text { Direct } \\
\text { Investment }\end{array}$ & $\begin{array}{c}\text { Other } \\
\text { Investments }\end{array}$ & Total & $\begin{array}{l}\text { Portfolio } \\
\text { Equity }\end{array}$ & $\begin{array}{c}\text { Portfolio } \\
\text { Debt }\end{array}$ & $\begin{array}{c}\text { Direct } \\
\text { Investment }\end{array}$ & $\begin{array}{c}\text { Other } \\
\text { Investments }\end{array}$ & Total \\
\hline NA & 0,19 & $-0,23$ & 0,24 & $-1,49$ & $-1,29$ & $-0,06$ & $-0,65$ & $-0,05$ & $-1,11$ & $-1,87$ \\
\hline LA & 0,51 & 0,22 & 1,15 & 1,71 & 3,59 & 0,43 & 1,82 & 6,17 & 0,45 & 8,86 \\
\hline EE & $-0,23$ & 0,34 & 0,69 & 0,81 & 1,61 & $-0,39$ & 0,11 & $-1,05$ & $-4,01$ & $-5,33$ \\
\hline WE & $-0,53$ & $-5,55$ & $-3,88$ & $-17,56$ & $-27,52$ & $-0,15$ & $-8,26$ & $-1,50$ & $-18,80$ & $-28,72$ \\
\hline EmA & $-0,56$ & 2,07 & 4,24 & 2,27 & 8,02 & $-4,91$ & 2,65 & 3,50 & 5,37 & 6,61 \\
\hline AS & $-0,64$ & $-0,49$ & 1,33 & 0,75 & 0,94 & $-0,21$ & $-0,38$ & 0,65 & 2,12 & 2,18 \\
\hline EME & $-0,04$ & 0,51 & 1,25 & 1,20 & 2,93 & $-0,73$ & 0,96 & 1,82 & $-1,02$ & 1,02 \\
\hline ADV & $-0,02$ & $-1,29$ & $-0,48$ & $-4,46$ & $-6,26$ & $-0,09$ & $-2,12$ & $-0,28$ & $-4,32$ & $-6,81$ \\
\hline WD & $-0,02$ & $-1,20$ & $-0,40$ & $-4,17$ & $-5,78$ & $-0,14$ & $-1,95$ & $-0,17$ & $-4,14$ & $-6,40$ \\
\hline
\end{tabular}

Source: Authors' calculations on the basis of balance of payments data (restricted sample).

Note: NA North America, LA Latin America, EE Eastern Europe, WE Western Europe, EmA Emerging Asia, AS Asia, EME emerging Market Economy, ADV advanced economies, WD World. 
- Finally, concerning the portfolio category, we need to distinguish between debt and equity (the former has fallen much more than the latter at the global level). Portfolio debt flows have fallen substantially for Western Europe and North America. By contrast, for equity the flows have fallen by a lesser extent.

Chart 9 below shows the composition of gross flows on the "asset" and on the "liability" side for advanced and for emerging market economies (the Chart Appendix shows these data for all G20 countries).

\subsection{Changing composition of international financial flows: explanatory factors and implications}

The changing composition of international financial flows documented above is a striking feature of the global economic environment. One may wonder what could have triggered this change, and what are the likely implications for the world economy. While it is usual to list separately the causes and the consequences for expositional purposes, several factors can be seen, both as a cause and a consequence. One obvious factor to underline in this respect is the fact that economic activity has been weak since the global financial crisis; the recovery has regularly disappointed, and international organizations such as the IMF have repeatedly revised their global growth forecasts downwards. Weak economic activity is both an explanatory factor for weak financial flows, and, since negative shocks are transmitted through financial linkages, a consequence. In this respect, the European crisis has played an important role. The fact that European periphery countries faced massive capital flights in recent years is documented in Buch et al. (2016), who investigate the role of Eurosystem liquidity provisions during the adjustment process.

Another key factor to underline is that some types of international financial flows seem to be inherently more volatile than others. In this respect, bank flows and portfolio flows are often described as "hot money" (see, for instance, Bluedorn et al., 2013). By contrast, FDI flows are typically more stable over time, which is why they are generally considered as a safer form of financing (in addition to other benefits they carry, such as technological transfers). One should of course nuance a little bit this appreciation, to the extent that "other investments" include very different components such as net credit and advances, which are not prone to particular instability (see Box A). One could also consider that flows in this category help to enhance global liquidity, as suggested, for instance, in CGFS (2011). Also, within portfolio flows, equities have been more resilient than debt. Yet, overall, the behavior of international financial flows after the global financial crisis reflects the traditional wisdom: the flows that are considered to be the most volatile are precisely those that saw the largest decline.

Chart 9 - The composition of international financial flows is contrasted between AEs and EMs
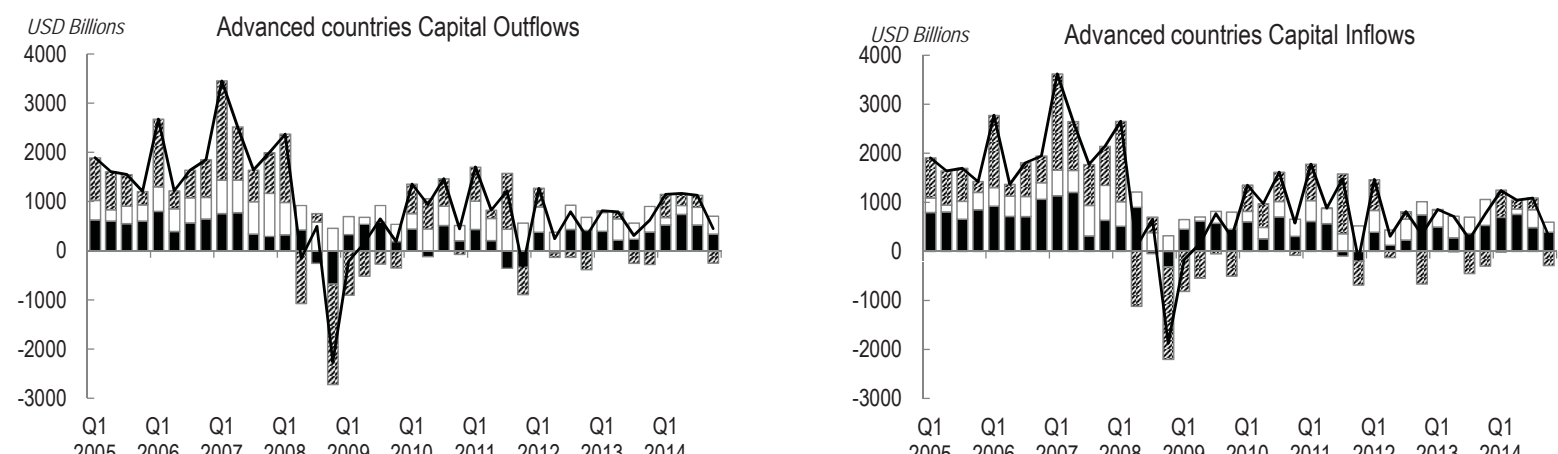

$-3000$

$\begin{array}{llllllllll}\text { Q1 } & \text { Q1 } & \text { Q1 } & \text { Q1 } & \text { Q1 } & \text { Q1 } & \text { Q1 } & \text { Q1 } & \text { Q1 } & \text { Q1 }\end{array}$
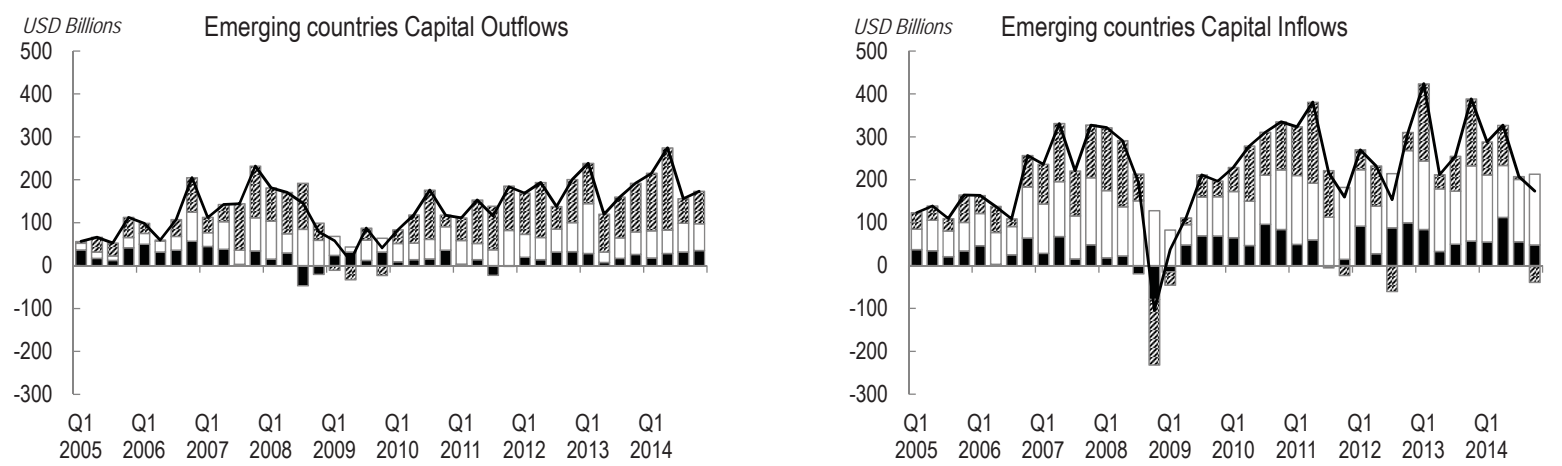

- Portfolio investment $\square$ Direct investment 


\section{Box A - A deeper look at the "other investment" category}

In our main text, we think broadly of the "other investment" category as bank flows, as it is generally assumed that they constitute the bulk of this category. This box gives more details on the exact composition of "other investment" in order to highlight the differences between banking flows and other sub-categories.

Other investments comprise the following types of financial flows: (1) Other equity, (2) Loans, (3) Currency and deposits, (4) Trade credit and advances, and (5) Other accounts receivable/payable. The last four components are categorized as debt instruments; it is not only possible to disaggregate these instruments by type of flow, but also by the counterparty, notably: (1) Central bank, (2) Deposit-taking corporations, except the central bank ("banks"), (3) General government, and (4) Other sectors.

The typical breakdown of the "other investment" category is displayed in Table A1: as it is easier to aggregate non-negative stocks than flows, Table A1 shows the International Investment Position (stocks of assets), rather than the Balance of Payments (outflows), of 10 major economies.

Table A1 shows that the part of the "other investment" category that can be attributed to banks fluctuates between $30 \%$ and $71 \%$. Whereas banks constitute the most important counterparty, the sub-category "Other sectors" also make up a large part - especially in countries such as the United States, Ireland and Luxembourg. A disaggregation of this counterparty is, however, not available for a large number of countries. Table A2 shows the breakdown of the counterparty "Other sectors" into financial (non-bank) corporations as well as nonfinancial corporations and households for a selected number of countries for which these data are available. For some countries (such as Luxembourg), adding the amounts from financial non-bank corporations to the amounts from banks sizably increases the contribution of the overall financial sector to the "other investment" category in the IIP.

Table A1 - Other investment in the International Investment Position (IIP), in billions USD, 2013

\begin{tabular}{|c|c|c|c|c|c|c|c|c|c|c|}
\hline & US & UK & $\mathrm{DE}$ & FR & $\mathrm{NL}$ & JP & LX & IR & $\mathrm{CH}$ & IT \\
\hline Assets, Other investment & 4367 & 5743 & 3329 & 2173 & 1244 & 1666 & 1382 & 1144 & 951 & 629 \\
\hline Other equity & & 9 & 84 & 48 & 8 & 57 & 0 & & 1 & 21 \\
\hline Currency and deposits & 1992 & 4168 & 2267 & 1447 & 824 & 140 & 301 & 378 & 670 & 232 \\
\hline Central bank & 0 & & 719 & 120 & 117 & & 148 & & 9 & 28 \\
\hline Banks & 801 & 2612 & 1080 & 999 & 561 & 64 & & 270 & 416 & 136 \\
\hline General government & & 1 & 38 & 1 & 2 & 0 & & 8 & 0 & \\
\hline Other sectors & 1190 & 1555 & 430 & 327 & 143 & 76 & 153 & 100 & 245 & 68 \\
\hline Loans & 2322 & 1534 & 785 & 604 & 266 & 1093 & 928 & 572 & 280 & 202 \\
\hline Central bank & & & & 16 & & & & 1 & 0 & \\
\hline Banks & 975 & 1480 & 558 & 495 & 107 & 634 & 589 & 74 & 195 & 117 \\
\hline General government & 90 & 5 & 153 & 82 & 24 & 192 & 1 & 0 & 1 & 76 \\
\hline Other sectors & 1257 & 49 & 73 & 11 & 135 & 267 & 339 & 497 & 83 & 9 \\
\hline Insurance schemes & & & 47 & & 10 & 7 & 28 & & & 48 \\
\hline $\begin{array}{l}\text { Trade credit and advances } \\
\text { Central bank }\end{array}$ & 53 & 2 & 116 & 69 & 54 & 71 & 9 & 56 & & 62 \\
\hline Banks & & & & & & & & & & 0 \\
\hline General government & & & 1 & 7 & & 3 & & & & \\
\hline Other sectors & 53 & 2 & 115 & 62 & 54 & 68 & 9 & 56 & & 62 \\
\hline $\begin{array}{l}\text { Other accounts receivable } \\
\text { Central bank }\end{array}$ & & 30 & 32 & 5 & 83 & 299 & 116 & 138 & & $\begin{array}{r}64 \\
1\end{array}$ \\
\hline Banks & & & 1 & 5 & 20 & 215 & & 4 & & 17 \\
\hline General government & & 13 & 2 & & 2 & 4 & 1 & 1 & & 31 \\
\hline Other sectors & & 17 & 28 & 0 & 62 & 80 & 115 & 132 & & 15 \\
\hline$\%$ Central bank & 0 & 0 & 22 & 6 & 9 & 0 & 11 & 0 & 1 & 5 \\
\hline$\%$ Banks & 41 & 71 & 49 & 69 & 55 & 55 & 43 & 30 & 64 & 43 \\
\hline$\%$ General government & 2 & 0 & 6 & 4 & 2 & 12 & 0 & 1 & 0 & 17 \\
\hline$\%$ Other sectors & 57 & 28 & 19 & 18 & 32 & 29 & 45 & 69 & 35 & 24 \\
\hline$\%$ Other equity & 0 & 0 & 3 & 2 & 1 & 3 & 0 & 0 & 0 & 3 \\
\hline$\%$ Insurance schemes & 0 & 0 & 1 & 0 & 1 & 0 & 2 & 0 & 0 & 8 \\
\hline
\end{tabular}

Source: Balance of Payments Statistics (BoPS), International Monetary Fund. US = United States, UK = United Kingdom, DE = Germany, $\mathrm{FR}=$ France, $\mathrm{NL}=$ Netherlands, $\mathrm{JP}=$ Japan, $\mathrm{LX}=$ Luxembourg, $\mathrm{IR}=$ Ireland, $\mathrm{CH}=$ Switzerland, $\mathrm{IT}=\mathrm{Italy}$.

Table A2 - Breakdown of private-sector positions (IIP), USD bn, 2013

\begin{tabular}{lrrrrrr}
\hline & UK & DE & FR & NL & LX & IT \\
\hline Sum Other sectors & 1623 & 647 & 400 & 394 & 616 & 154 \\
Sum Other financial corporations & 1240 & 373 & 252 & 297 & 607 & 14 \\
Sum Nonfinancial corporations and households & 383 & 274 & 148 & 97 & 9 & 140 \\
Sum Banks & 4092 & 1639 & 1499 & 688 & 589 & 270 \\
Sum Private financial sector & 5332 & 2012 & 1752 & 985 & 1195 & 284 \\
\% Financial sector: Banks & 71 & 49 & 69 & 55 & 43 & 43 \\
\% Financial sector: Non-banks & 22 & 11 & 12 & 24 & 44 & 2 \\
\% Financial sector & 93 & 60 & 81 & 79 & 86 & 45 \\
\hline
\end{tabular}

Source: Balance of Payments Statistics (BoPS), International Monetary Fund. UK = United Kingdom, DE = Germany, FR $=F r a n c e, ~ N L=$ Netherlands, LX $=$ Luxembourg, IT = Italy.

Having established that banks and non-bank financial institutions make up a large part of the "other investment" category in terms of stocks, the question is whether these counterparties also drive much of the flows that are observed in the Balance of Payments. The underlying intuition is that the stocks in the International Investment Position due to banks can remain entirely stable and that its overall movement is entirely driven by large movements in the other sub-categories. 
Table A3 shows that the picture is indeed not as clearcut in the Balance of Payments, especially as flows can take on negative amounts. As gross outflows, or more accurately the net acquisition of financial assets, can be negative (both in total as well as for certain sub-categories), the aggregate positions mask substantial heterogeneity among the sub-categories, which tend to cancel each other out. As such, bank flows might drive other investments to a large extent (as for example in the case of Switzerland where $95 \%$ of outflows of other investments are driven by bank flows) or actually only represent a small fraction and a counterbalancing force (as for example in the case of the Netherlands where banks flows are positive and small while, overall, other investment flows are negative and comparatively large).

Table A3 - Other investment in the Balance of Payments (BoP), USD bn, 2013

\begin{tabular}{lrrrrrrrrrr}
\hline & US & UK & DE & FR & NL & JP & LX & IR & CH & IT \\
\hline Net acquisition of assets & -228 & -327 & -247 & -6 & -56 & 185 & 333 & -66 & 78 & -34 \\
Sum Central bank & -9 & 0 & -194 & -26 & -92 & 0 & -2 & 0 & 3 & 13 \\
Sum Banks & -123 & -429 & -75 & 27 & 4 & 78 & 19 & -58 & 74 & -58 \\
Sum General government & 6 & 2 & -3 & 10 & 1 & 7 & 0 & 4 & 0 & 9 \\
Sum Other sectors & -103 & 99 & 12 & -30 & 27 & 99 & 311 & -12 & 1 & -8 \\
Other equity & 0 & 2 & 13 & 11 & 3 & 1 & 0 & 0 & 0 & 10 \\
Insurance schemes & 0 & 0 & 0 & 0 & 1 & 0 & 5 & 0 & 0 & 0 \\
\hline
\end{tabular}

Source: Balance of Payments Statistics (BoPS), International Monetary Fund. UK $=$ United Kingdom, DE $=$ Germany, FR $=$ France, $\mathrm{NL}=$ Netherlands, $\mathrm{LX}=$ Luxembourg, $I T=$ Italy.

We thus note that there is substantial heterogeneity across countries and sub-categories as well as important differences between stocks and flows. Despite these caveats, the question remains what drives other investments in the Balance of Payments at the global level. Inspecting the disaggregation of the other investment category, Figure A1 shows that the overall level of other investments up to end-2009 is largely driven by the sum of flows from banks and other sectors. The contribution of bank flows to the positive net acquisition of foreign assets (outflows) up to $2008 \mathrm{Q} 1$ is on average $68 \%$, whereas that of other sector flows is on average $29 \%$. The collapse of net acquisitions of foreign assets in the "other investment" category in $2008 \mathrm{Q} 4$ and the subsequent quarters is once again driven by large negative bank and other sector flows. However, from 2010 onwards, the picture is less clearcut. One first notes that bank (and other sector) flows are of considerably smaller magnitude. Second, the two sub-categories do not seem to move in the same direction as during the crisis and pre-crisis period. As flows from banks and flows from other sectors sometimes have opposite signs, overall other investment flows are considerably smaller on aggregate. Third, one notes the increasing relative importance of public-sector flows (central bank and general government) which tend to sometimes reinforce and sometimes attenuate the flows from the private sector (banks and other sectors).

Figure A1 - Disaggregation of other investment (BoP), world *

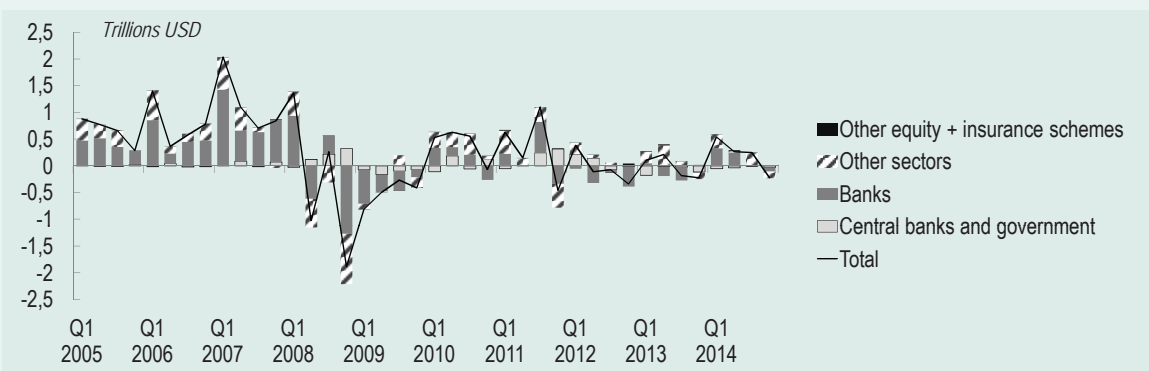

* The countries included are: Argentina, Australia, Austria, Belgium, Brazil, Canada, Chile, Colombia, Czech Republic, Denmark, Finland, France, Germany, Greece, Hungary, India, Indonesia, Ireland, Israel, Italy, Japan, Korea, Luxembourg, Malaysia, Mexico, Netherlands, New Zealand, Norway, Peru, Poland, Portugal, Romania, Russia, South Africa, Sweden, Switzerland, Thailand, Turkey, Ukraine, United Kingdom, and United States.

Source: Balance of Payments Statistics (BoPS), International Monetary Fund.

As established above, the contraction in other investments during the crisis is largely due to a contraction of banking flows (as well as the contraction of other sector flows, which are presumably driven by non-bank financial sector flows). One question that arises is whether this contraction affects all counterparty sectors to the same extent. This distinction is relevant, as different counterparties imply different types of lending, such as interbank lending or direct cross-border credit to non-financial corporations. Knowing which counterparties are affected suggests different implications with regard to the underlying drivers of movements in flows and stocks, regulatory policies or financial stability at large.

One drawback of Balance of Payments data is that the counterparty (both in terms of residence and sector) is only known unilaterally, i.e. the amounts the banking sector in a given country holds vis-à-vis non-residents are known, but it is not known which country and which sector receives these flows. A comparison with the BIS International Banking Statistics can therefore be quite useful, as these data represent a sub-category of the International Investment Position. In particular, the BIS Locational Banking Statistics, which are organized around the residency principle as are the BoP/IIP Statistics, collect outstanding amounts of banking flows, disaggregated by several dimensions such as residence and sector of the counterparty. In terms of type of instruments, the BIS category "Loans and deposits" closely matches the sum of "Loans" and "Currency and deposits" in the other BoP/ IIP for some of the countries*. Discrepancies arise most likely due to different reporting standards. ${ }^{* *}$

* One should note a particularity with regard to the treatment of loans and deposits of banks on the assets and liabilities side of the BoP/IIP. Whereas a loan of a bank in country A vis-à-vis a non-bank company in country B is characterized as a loan, a loan of a bank in country A vis-à-vis a bank in country $B$ is characterized as a deposit. An inverse transaction, i.e. a loan of a non-bank company in country B vis-à-vis the bank in country $A$, represents a liability from the point of view of the bank in country $A$ and is categorized as a deposit. Thus, whereas interbank loans are characterized as deposits from the point of view of both assets and liabilities, a loan between a bank and a non-bank company is characterized as a loan on the asset side and as a deposit on the liability side. See paragraphs 5.40 and 5.42 of the Balance of Payments Manual.

** The differences are most pronounced for the US and Japan. For the former, McCauley and Seth (1992) and Borio et al. (2011), respectively, have noted that the amounts of the BIS International Banking Statistics considerably outnumber the ones from the US flow of funds. According to McCauley and Seth (1992), underreporting in the flow of funds could be due to uncertainty about where a loan is actually booked. 
Table A4 - Comparison between IIP/BoP data and BIS Locational Banking Statistics, USD bn, 2013

\begin{tabular}{lrrrrrrrrrr}
\hline & US & UK & DE & FR & NL & JP & LX & IR & CH & IT \\
\hline BIS stocks & 3140 & 4087 & 1637 & 1495 & 669 & 1159 & 583 & 274 & 525 & 243 \\
IIP (stocks) & 1776 & 4092 & 1638 & 1495 & 669 & 697 & 589 & 344 & 612 & 253 \\
BIS flows (exchange rate adjusted) & -264 & -444 & -67 & 56 & 10 & 18 & 16 & -41 & 30 & -58 \\
BoP (flows) & -123 & -429 & -75 & 26 & 5 & 107 & 19 & -58 & 74 & -55 \\
\hline
\end{tabular}

Source: Balance of Payments Statistics (BoPS), International Monetary Fund and Locational Banking Statistics (by residence) in the International Banking Statistics, Bank for International Settlements. US = United States, UK = United Kingdom, DE = Germany, FR $=$ France, $\mathrm{NL}=$ Netherlands, $\mathrm{JP}=$ Japan, $\mathrm{LX}=$ Luxembourg, $\mathrm{IR}=$ Ireland, $\mathrm{CH}=$ Switzerland, IT = Italy.

Bearing the caveat of reporting discrepancies in mind, we are able to disaggregate bank loans and deposits by their counterparty using BIS data on cross-border banking flows. Figure A2 shows that the contraction during the crisis was largely driven by a slump in interbank lending; lending to non-bank actors also contracted, though to a lesser extent. However, one should bear in mind that the non-bank sector also comprises financial corporations that are not banks. The post-crisis period, in particular the years 2012 and 2013, is characterized by negative flows largely driven by the interbank market. Part of these contractions is driven by intra-group flows (i.e. cross-border bank lending among banks that belong to the same banking group); however, a disaggregation of these flows in the BIS Locational Banking Statistics is only available since 2014.

Figure A2 - Disaggregation of bank loans and deposits, world*

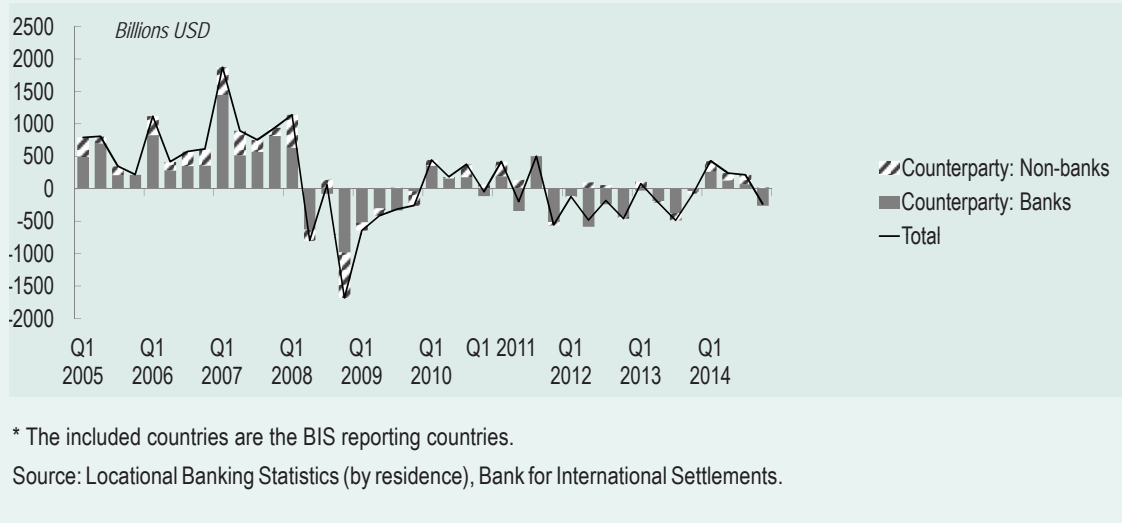

The different components of financial flows have therefore been faithful to their reputation: "hot money" (with the exception of equity flows) has evaporated quickly, whereas FDI has been more robust. Looking forward, this may suggest more stable flows as the resulting composition is richer in the more stable FDI flows. However, other elements need to be considered as well to get a full assessment. Table 4, which presents key statistics on the volatility of the main categories of financial flows during the main subperiods considered here (and for the whole sample), confirm these established stylized facts (bearing in mind of course that both sub-periods are short, thus enabling few observations to calculate these statistics). For instance, FDI, which was less volatile than "other investments" before the crisis, was also less volatile after the crisis.

The factors behind the collapse in cross-border banking flows have been analyzed in CGFS (2011), which investigated the question of global liquidity and focused on bank flows as the prime measure of global liquidity. Among the possible explanatory factors, the paper by CGFS (2011) highlighted the role of risk aversion, proxied by the VIX index. However, the negative relation between the two does not work any longer. Chart 10 reports the VIX, together with the policy indicators calculated by Bloom (2014) and Bloom et al. (2007). The rise of the VIX in the wake of Lehman Brothers correlates well with the drop in capital flows that took place during this period. The VIX has considerably abated since then, but this is not associated with a rebound in capital flows. The other uncertainty indicators do not seem to point to a high degree of uncertainty in recent years, suggesting that uncertainty does not play a central role in the weakness of financial flows.

To some extent, the fall in bank flows could be interpreted as a correction from the "global banking glut" that prevailed in the pre-crisis period (Shin, 2011), through which European banks helped to enhance intermediation capacities in the US. These considerations represent a convincing argument as to why it is important to look at gross and not just net international financial flows. Meanwhile, recently, McQuade and Schmitz (2016) have looked into the cross-country heterogeneity of gross capital flows. They found, in particular, that gross inflows in the postcrisis period (which is defined slightly differently from ours) were higher for the countries with smaller external and internal imbalances in the pre-crisis period.

Table 4 - Volatility of flows by sector and by subperiods (coefficient of variation)

\begin{tabular}{lcccc}
\hline & $\begin{array}{c}\text { Portofolio } \\
\text { Equity }\end{array}$ & $\begin{array}{c}\text { Portofolio } \\
\text { Debt }\end{array}$ & $\begin{array}{c}\text { Direct } \\
\text { Investment }\end{array}$ & $\begin{array}{c}\text { Other } \\
\text { Investment }\end{array}$ \\
\hline World pre-crisis & 0,36 & 0,24 & 0,30 & 0,55 \\
World post-crisis & 0,41 & 0,64 & 0,28 & 6,24 \\
World total period & 0,92 & 1,08 & 0,34 & 2,59 \\
\hline
\end{tabular}

Source: Author's calculations. 


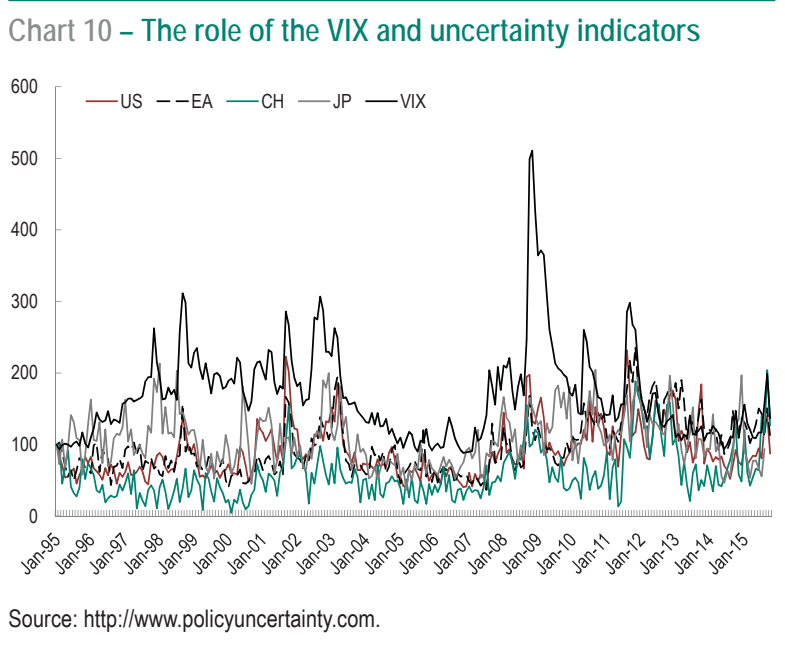

The fact that international banking flows have fallen dramatically could also reflect the disintermediation process that intensified in the wake of the global financial crisis. ${ }^{15}$ In turn, this process could result from different factors. Several prominent observers have pointed out the effect of financial regulation reforms, which could explain why the banking sector seems to be losing ground, compared to financial markets (see, for instance, Tarullo (2012, 2014), CGFS (2010), Gambacorta and Van Rixtel (2013), etc.). This particular factor can be seen as a more permanent component than other determinants such as the VIX. Several studies have also pointed out that the exceptional measures put in place after the crisis have a substantial domestic bias, which could have played a role in the global retrenchment process (see e.g. Beck et al., 2015; Forbes, Reinhart and Wiedalek, 2015). The IMF GFSR (2015) summarizes these different elements: "Although the cutback in cross-border lending was triggered by the crisis, regulatory changes and weaknesses in bank balance sheets have contributed significantly to the subsequent retrenchment."

Moreover, it is also possible that local lending by affiliates has (partly) replaced cross-border lending. Still, according to the GFSR (2015), "The relative shift on the part of foreign banks away from cross-border lending and toward more local lending through affiliates has a positive effect on the financial stability of host countries. Cross-border lending compounds adverse domestic and global shocks. In contrast, foreign-owned subsidiaries, particularly those with better-capitalized parent banks, tend to behave less procyclically than domestic banks around domestic crises."

Another potential explanatory factor lies in the recent weakness of international trade flows (as documented, for instance, by Hoekman, 2015). Indeed, trade credits are included in the "other investment" category, such that the weakness of international trade will mechanically affect this type of flow. One element to bear in mind, however, is that causality can run both ways. Indeed, trade credit issues have been highlighted as one of the potential causes of weak trade (see, for instance, Hahn, Amity and

(15) One caveat perhaps is that disintermediation suggests that one type of flow (portfolio flows) would substitute another type (bank flows), whereas Section 3 showed that there was no substitution: the fall in bank flows was not compensated by another type of flow.
Weinstein, 2011, or Chor and Manova, 2012). More importantly, trade credits amount to fairly low levels and cannot account for the fall in investment flows. On the other hand, another explanation could relate the fall of trade and financial flows. Indeed, Aviat and Coeurdacier (2007) find (using instrumental variables to account for the fact that both variables are endogenous) that the two types of flow are complementary in a gravity framework.

\section{Conclusion}

This policy brief has presented four main stylized facts on international financial flows in recent times, focusing on the comparison with the pre-crisis period. (i) Overall, international capital flows have dried up, now averaging at barely half of their pre-crisis level in percentage of world GDP. (ii) In terms of geographical distribution, this fall has mainly affected advanced countries, especially in Western Europe, while for emerging market economies the flows have actually increased. (iii) Net capital flows have also recorded notable changes, falling significantly to an order of magnitude that mirrors to a large extent the changes registered in the current account. (iv) The composition of international capital flows has changed dramatically, due to the heterogeneous change in their sectoral composition: bank flows have been very markedly affected, whereas FDI has remained roughly unchanged at the global level. Within portfolio investments, debt flows have fallen much more than equity flows (Western Europe being again the region of the world where debt flows have fallen most).

Several factors can be put forward to explain these changes. They range from general factors, such as the weakness in the global recovery and the associated degree of uncertainty, to more specific factors, affecting certain regions and sectors more than others. Among the latter, the European crisis seems to have played a key role, as it is really flows to and from Western Europe that shrank the most. Regarding the sectoral composition, several explanations can be put forward for the collapse in bank flows. The need to repair bank balance sheets and the substitution of crossborder flows by local lending by affiliates have been documented extensively. In addition, regulation may have played a role (GFSR, 2015, for instance).

The consequences of these changes, for financial stability issues, are not clear at this stage. The fact that the share of "hot money" has gone down while that of FDI has increased may lead to a more stable international monetary system, but the concept of "hot money" remains somewhat elusive (bearing in mind that many operations under the "other investment" flows contribute to the liquidity of markets) and it is hard to gauge if the pre-crisis properties and specificities of the various types of flows that we focused on will prevail in the "new normal". That said, "hot money" may actually impose discipline on the receiving countries, which are exposed to sudden stops in case of hazardous macroeconomic management. The changes that have taken place since the global financial crisis may correspond to a simple normalization, as suggested for instance by Coeuré (2015), after rather "exuberant" times in the pre-crisis period. 


\section{Box B - Lessons from the US TIC data}

The above analysis focused on quarterly BoP data from the IMF balance of payments statistics, which allows comparison across countries. However, more can be learnt by turning to country-specific databases. In particular, the US Treasury International Capital (TIC) data provide a wealth of information on the world's largest economy, at a monthly frequency. Two key lessons can be drawn from the data.

The first lesson is that the level of net TIC flows has fallen substantially in recent years. As the TIC data* tend to be volatile, Chart B1 shows the net flows using a 12-month rolling window. The flows are much below the pre-crisis level and back to the level they had in the mid-1990s.

The second lesson is that net flows are currently a lot more volatile than they used to be (Chart B2, which shows the variance of the net TIC flows, calculated over a 12-month window).

Figure B1 - Total, net TIC flows

(12 months rolling sum, USD bn)

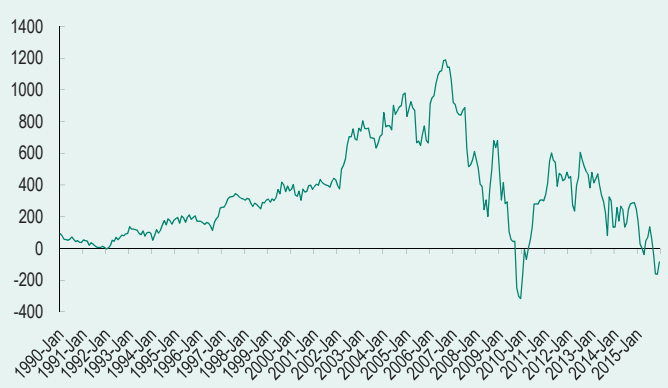

Figure B2 - Variance, net TIC flows (12 months rolling window, USD bn)

Source: Treasury International Capital data, US Treasury.

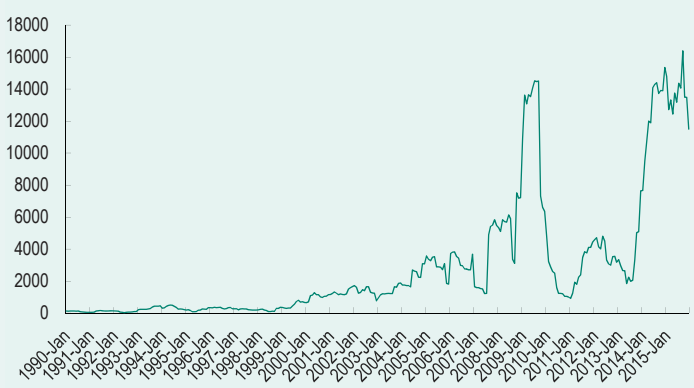

* Last observation: December 2015. Treasury International Capital (TIC) data accessed on February 17, 2016, at http://www.treasury.gov/resource-center/data-chart-center/ tic/Pages/ticpress.aspx.

\section{Box C - Portfolio flows from the EPFR database}

This box focuses on an alternative database that is often used to comment on portfolio flows to and from emerging market economies - EPFR (Emerging Portfolio Research). This database has several key assets compared to the balance of payment data used in the core of the text: it is available at a much higher frequency, including monthly and, from 2001, weekly, and until a more recent period of time. On the other hand, it is not directly comparable to the balance of payment data as it is collected using a different method. In particular, EPFR collects data from financial funds domiciled globally, while balance of payment data is meant to be comprehensively collected according to the resident/non-resident criterion. One limitation of EPFR is its limited coverage and possible bias; in particular, a substantial fraction of funds included in the EPFR sample is domiciled in (onshore) developed countries.

With these caveats in mind, it is useful to look at the EPFR data, which point to a substantial decline in flows to EMEs in the course of 2013 (turning negative at the end of 2013 and remaining negative for most of the subsequent period, so significantly below balance of payment data).). This seems to be the case for all EMEs, whereas there is more heterogeneity across AEs.
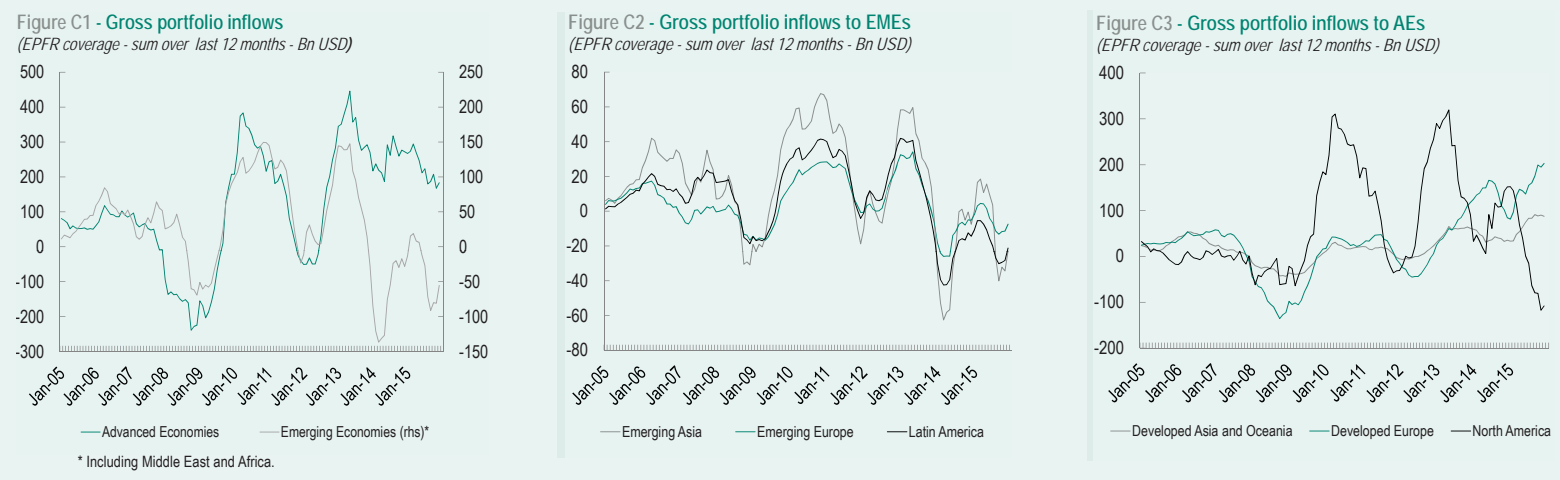

Source: EPFR. 
Adler, Gustavo, Marie-Louise Djigbenou and Sebastian Sosa (2016), "Global financial shocks and foreign asset repatriation: Do local investors play a stabilizing role?", Journal of International Money and Finance, 2016, Volume 60 , Issue C, pp. 8-28.

Ahn, JaeBin, Mary Amity and David E. Weinstein (2011), "Trade Finance and the Great Trade Collapse", American Economic Review, Papers and Proceedings, pp. 298-302.

Albuquerque, Rui (2003), "The composition of international capital flows: risk sharing through foreign direct investment", Journal of International Economics, Vol. 61(2), Dec. 2003, pp. 353-383.

Alberola, Enrique, Aitor Erce and José María Serena (2016), "International reserves and gross capital flows dynamics", Journal of International Money and Finance, 2016, Volume 60, Issue C, pp. 151-71.

Aviat, Antonin and Coeurdacier, Nicolas (2007), "The geography of trade in goods and asset holdings", Journal of International Economics, Elsevier, vol. 1(1), pages 22-51, March.

Baldwin, Richard (2009), "The Great Collapse: Causes, Consequences and Prospects", a VOXEU publication, 27 November 2009.

Beck, Roland, John Beirne, Francesco Paternò, Jolanda Peeters, Julio RamosTallada, Cyril Rebillard, Dennis Reinhardt, Lisa Weissenseel and Julia Wörz (2015), "The side effects of national financial sector policies: framing the debate on financial protectionism", Occasional Paper Series, No 166, September 2015.

Blanchard, Olivier J, Marcos Chamon, Atish R. Ghosh, and Jonathan Ostry (2015), "Are Capital Inflows Expansionary or Contractionary? Theory, Policy Implications, and Some Evidence", CEPR Discussion Paper No. DP10909, November 2015.

Bloom, Nick (2014), "Fluctuations in Uncertainty", Journal of Economic Perspectives, 28(2):153-176

Bloom, Nick, Bond, Stephen and John Van Reenen (2007), "Uncertainty and Investment Dynamics", Review of Economic Studies, Vol. 74, pp. 391-415.

Bluedorn, John C., Rupa Duttagupta, Jaime Guajardo and Petia Topalova (2013), "Capital Flows are Fickle: Anytime, Anywhere", IMF Working Papers 13/183, International Monetary Fund.

Borio, Claudio and Piti Disyatat (2015), "Capital flows and the current account: Taking financing (more) seriously", BIS Working Paper No. 525, October 2015.

Borio, Claudio, Robert McCauley and Patrick McGuire, 2011. "Global credit and domestic credit booms," BIS Quarterly Review, Bank for International Settlements.

Boz, Emine, Matthieu Bussière and Clément Marsilli (2014), "On the recent slowdown in global trade", VOXEU, Nov. 2014.

Bracke, Thierry, Matthieu Bussière, Michael Fidora and Roland Straub (2008), "A Framework for Assessing Global Imbalances", Occasional Paper Series 78, European Central Bank.

Broner, Fernando, Tatiana Didier, Aitor Erce, and Sergio Schmukler (2013), "Gross capital flows: Dynamics and crises", Journal of Monetary Economics, Elsevier, Vol. 60(1), pages 113-133.

Brukoff, Patricia and Bjorn Rother (2007), "FDI May Not Be as Stable as Governments Think", IMF Survey Magazine, https://www.imf.org/external/ pubs/ft/survey/so/2007/RES051A.htm.

Buch, Claudia and Linda Goldberg (2015), "International Banking and Liquidity Risk Transmission: Lessons from across Countries", IMF Economic Review, Vol. 63, No. 3

Buch, Claudia M., Manuel Buchholz, Alexander Lipponer and Esteban Prieto (2016), "Liquidity Provision, Financial Vulnerability, and Internal Adjustment to a Sudden Stop", Bundesbank mimeo.

Bussière, Matthieu and Marcel Fratzscher (2008), "Financial Openness and Growth: Short-run Gain, Long-run Pain?", Review of International Economics, Wiley Blackwell, Vol. 16(1), pages 69-95, 02.

Cetorelli, Nicola and Linda Goldberg (2011), "Global Banks and International Shock Transmission: Evidence from the Crisis", IMF Economic Review, Vol. 9(1), pp. 41-76, April.
Cetorelli, Nicola and Linda Goldberg (2012), "Liquidity Management of U.S Global Banks: Internal Capital Markets in the Great Recession", Journal of International Economics, Vol. 88(2), pp. 299-311.

Chinn, Menzie D and Hiro Ito (2006), "What Matters for Financia Development? Capital Controls, Institutions, and Interactions", Journal of Development Economics, Vol. 81(1), pp. 163-192, October.

Chor, Davin and Kalina Manova (2012), "Off the Cliff and Back? Credit Conditions and International Trade During the Global Financial Crisis", Journal of International Economics, Vol. 87, pp. 117-133.

Coeuré, Benoît (2015), "Paradigm lost: Rethinking international adjustments", Egon and Joan von Kashnitz Lecture, Clausen Center for International Business and Policy, Berkeley, 21 November 2015

Committee on the Global Financial System (2010), "Funding patterns and liquidity management of internationally active banks", CGFS Report No. 39 May.

Committee on the Global Financial System (2011), "Global liquidity - concept, measurement and policy implications", CGFS Papers No. 45.

Erce, Aitor and Daniel Riera-Crichton (2015), "Catalytic IMF? A gross flows approach", ESM Working Paper 9.

Forbes, Kristin, Marcel Fratzscher, and Roland Straub (2015), "Capital-flow management measures: What are they good for?", Journal of International Economics, Elsevier, Vol. 96(S1), pages S76-S97.

Forbes, Kristin J., Dennis Reinhardt and Tomasz Wiedalek (2015), "The Spillovers, Interactions, and (Un)Intended Consequences of Monetary and Regulatory Policies", 16th Jacques Polak Annual Research Conference, November 5-6, 2015

Forbes, Kristin J., and Francis E. Warnock (2012), "Capital Flow Waves: Surges, Stops, Flight, and Retrenchment", Journal of International Economics, No. 88, pp. 235-51.

Fratzscher, Marcel (2011), "Capital Flows, Push versus Pull Factors and the Global Financial Crisis", Journal of International Economics, Elsevier, Vol. 88(2), pages 341-356.

Gambacorta, Leonardo, and Adrian Van Rixtel (2013), "Structural Bank Regulation Initiatives: Approaches and Implications", BIS Working Papers No. 412.

Gaulier, Guillaume, Gianluca Santoni, Daria Taglioni and Soledad Zignago (2014), "The power of the few in determining trade accelerations and slowdowns", in B. Hoekman, The Global Trade Slowdown: A New Normal? a VoxEU.org eBook.

Ghosh, Atish R., Qureshi, Mahvash S., Kim, Jun II and Juan Zalduendo (2014), "Surges", Journal of International Economics, Elsevier, Vol. 92(2), pages 266-285.

Hale, Galina and Maurice Obstfeld (2014), "The Euro and the Geography of International Debt Flows," NBER Working Papers 20033.

Hoekman, Bernard (2015), The Global Trade Slowdown: A New Normal? CEPR eBook, June 24, 2015, \{HYPERLINK "http://www.voxeu.org/content/ global-trade-slowdown-new-normal"\}

International Monetary Fund (2012), "The Liberalization and Management of Capital Flows: An Institutional View". Available at: http://www.imf.org/ external/np/pp/eng/2012/111412.pdf

International Monetary Fund (2015), Global Financial Stability Review, Chapter 2, "International Banking After the Crisis: Increasingly Local and Safer?", April 2015.

Kaminsky, Graciela and Sergio Schmukler (2003), "Short-Run Pain, LongRun Gain: The Effects of Financial Liberalization”, NBER Working Papers 9787, National Bureau of Economic Research, Inc

Levchenko, Andrei A. and Paolo Mauro (2007), "Do Some Forms of Financial Flows Help Protect Against 'Sudden Stops'?", World Bank Economic Review, Vol. 21(3), September 2007, pp. 389-411.

Lucas, Robert Jr. (1990), "Why Doesn't Capital Flow from Rich to Poo Countries?", American Economic Review, American Economic Association, Vol. 80(2), pp. 92-96, May. 
McCauley, Robert N. and Rama Seth, (1992), "Foreign bank credit to US corporations: the implications of offshore loans", Quarterly Review, Spring, Federal Reserve Bank of New York, pp. 52-65.

McQuade, Peter and Martin Schmitz (2016), "The Great Moderation in International Capital Flows: a Global Phenomenon?", mimeo.

Milesi-Ferretti, Gian Maria, and Cédric Tille (2011), "The Great Retrenchment: International Capital Flows during the Global Financial Crisis", Economic Policy, Vol. 66, pp. 28-346.

Obstfeld, Maurice (2012), "Does the Current Account Still Matter?", American Economic Review, American Economic Association, Vol. 102(3), pages 1-23, May.

Ostry, Jonathan D., Atish R. Ghosh, Marcos Chamon and Mahvash S. Qureshi (2011), "Capital Controls: When and Why?", IMF Economic Review, 59, pp. 562-580

Ostry, Jonathan D., Atish R. Ghosh, Marcos Chamon and Mahvash S. Qureshi (2012), "Tools for Managing Financial-Stability Risks from Capital Inflows", Journal of International Economics, 88(2), pp. 407-421.

Pasricha, Gurnain, Matteo Falagiarda, Martin Bijsterbosch, Joshua Aizenman (2015), "Domestic and Multilateral Effects of Capital Controls in Emerging Markets", Working Paper 2015-37, Oct. 2015

Prasad, Eswar S., Raghuram G. Rajan and Arvind Subramanian (2007), "Foreign Capital and Economic Growth", Brookings Papers on Economic Activity, Vol. 38(1), pp. 153-230.
Puy, Damien (2015), "Mutual funds flows and the geography of contagion", Journal of International Money and Finance, 2016, Vol. 60, Issue C, pp. 73-93. Quinn, Dennis, Martin Schindler and A. Maria Toyoda (2011), "Assessing Measures of Financial Openness and Integration", IMF Economic Review, Vol. 59(3), pp. 488-522, August.

Reinhart, Carmen and Vincent Reinhart (2009), "Capital Flow Bonanzas: An Encompassing View of the Past and Present", NBER Chapters, in: NBER International Seminar on Macroeconomics 2008, p. 9-62, National Bureau of Economic Research, Inc.

Rey, Hélène (2013), "Dilemma not Trilemma: The Global Financial Cycle and Monetary Policy Independence", Jackson Hole Paper August 2013.

Shin, Hyun Song (2011), "Global Banking Glut and Loan Risk Premium", $12^{\text {th }}$ Jacques Polak Annual Research Conference, 10-11 November 2011.

Tarullo, Daniel (2012), "Regulation of Foreign Banking Organizations", Board of Governors of the Federal Reserve System, Speech at the Yale School of Management Leaders Forum.

Tarullo, Daniel (2014), Opening Statement by Gov. Daniel K. Tarullo, "Enhanced Prudential Standards for Bank Holding Companies and Foreign Banking Organizations".

Tille, C., and E. van Wincoop, (2010), "International Capital Flows", Journal of International Economics, 80, 157-75

\section{About the authors}

Matthieu Bussière is Deputy Director in the Directorate Economics and International and European Relations at the Banque de France, Julia Schmidt is Economist in the same Directorate and Natacha Valla is Deputy Director at CEPII.

Corresponding Author: Matthieu.bussiere@banque-france.fr 


\section{Chart Appendix 1}

Chart - Balance of Payment Data for the $\mathbf{G} 20$ countries: Gross Inflows and Outflows (Total and by Sector) (USD billions)
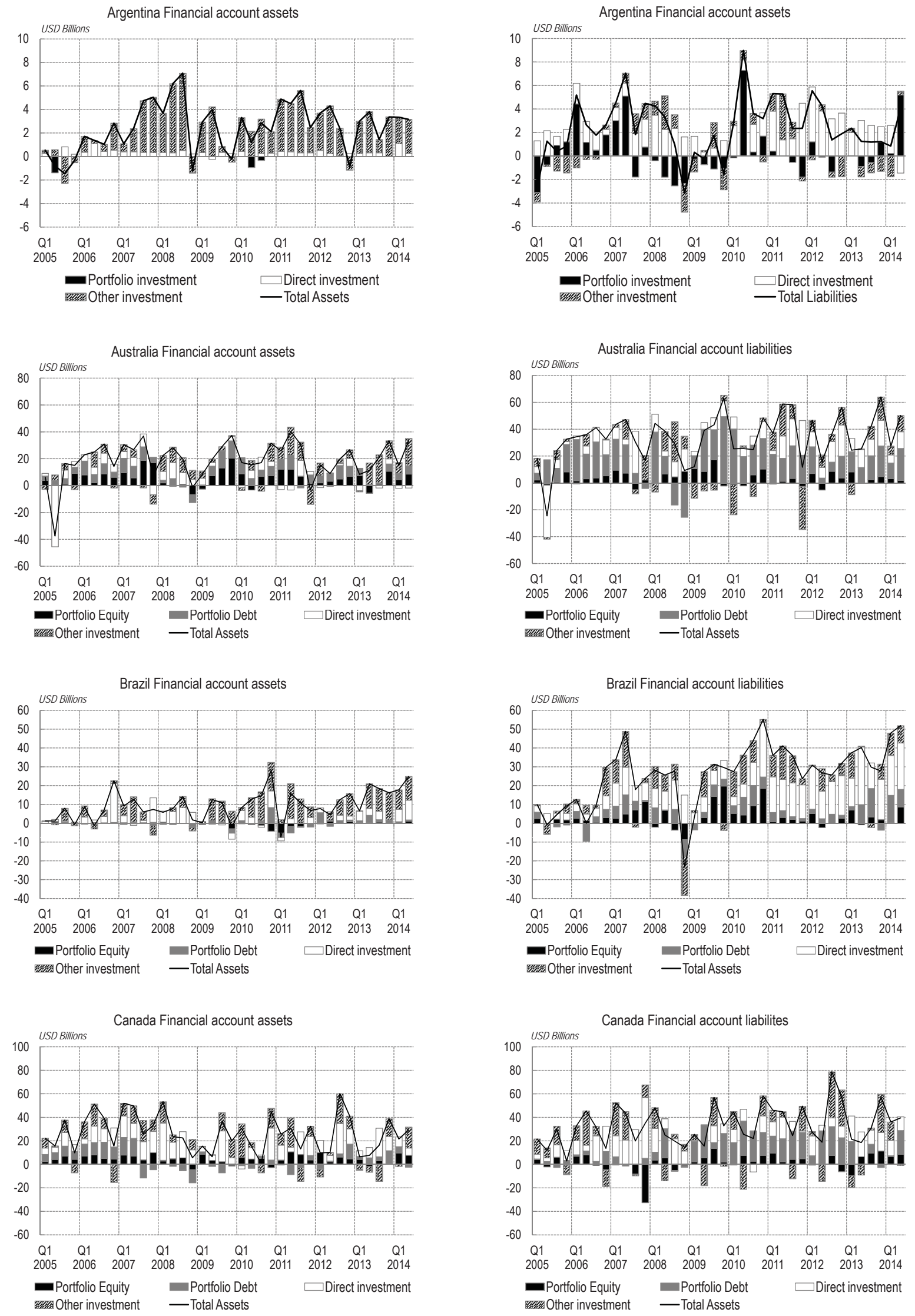

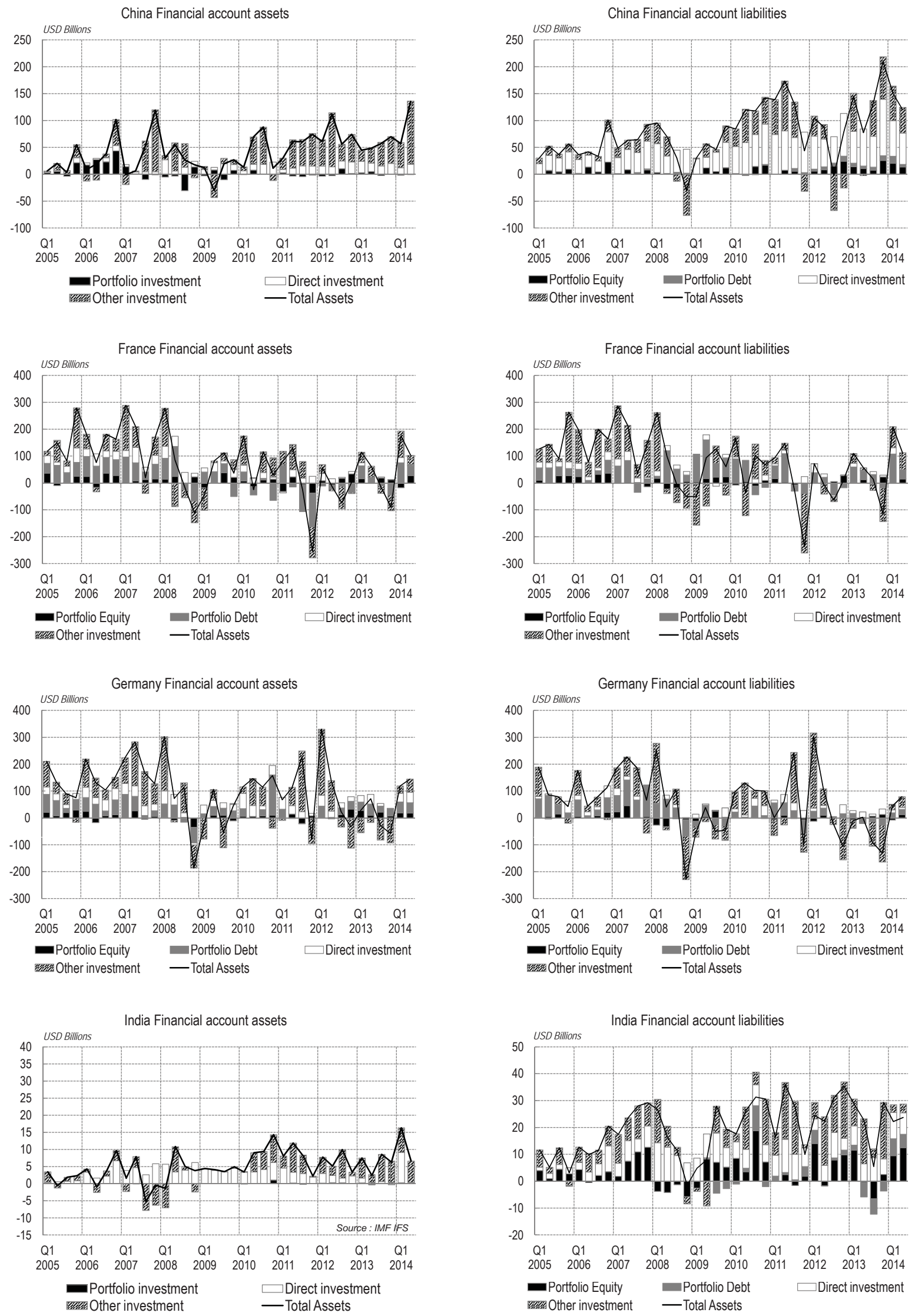

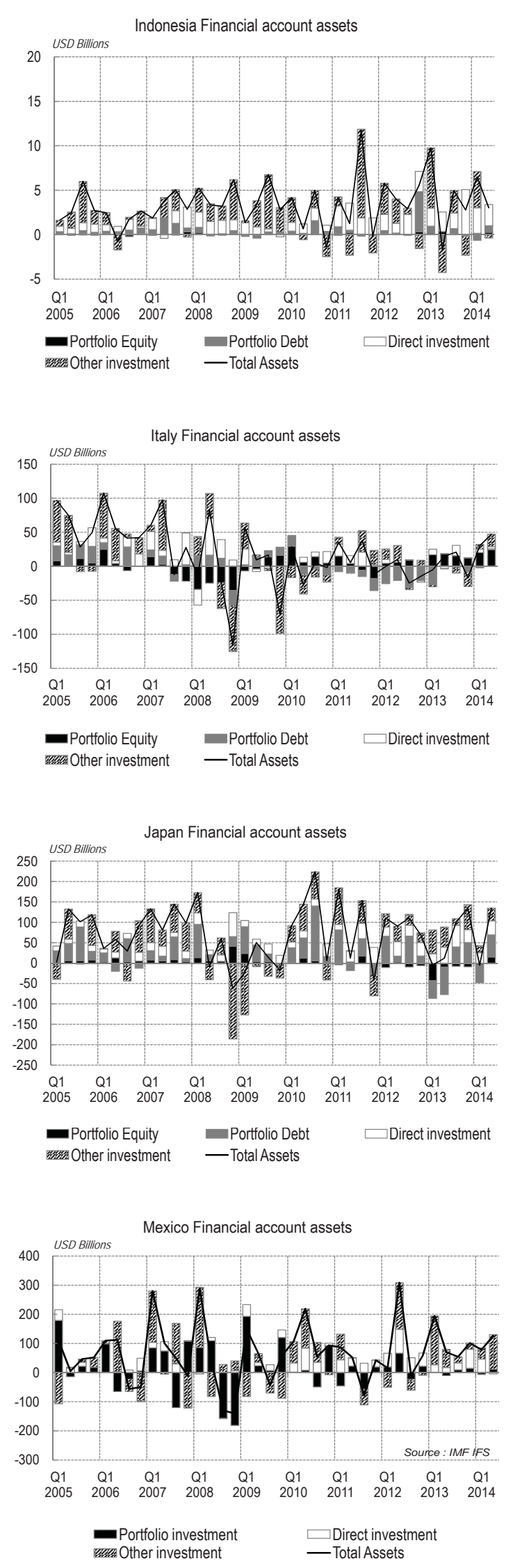
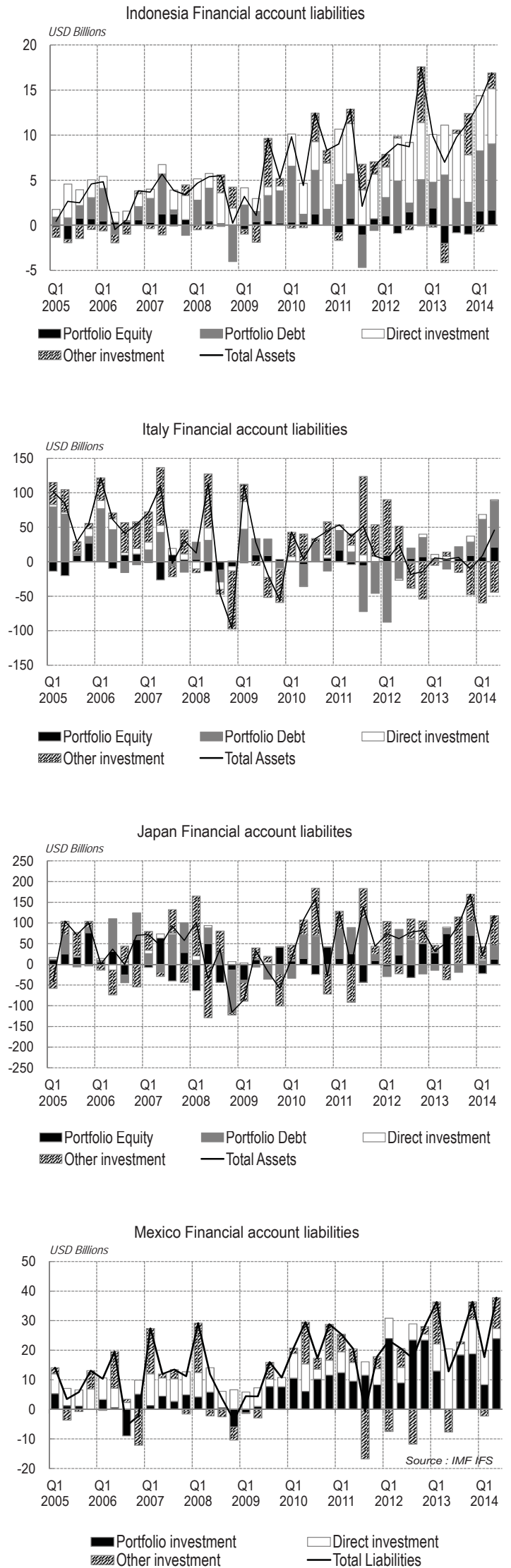


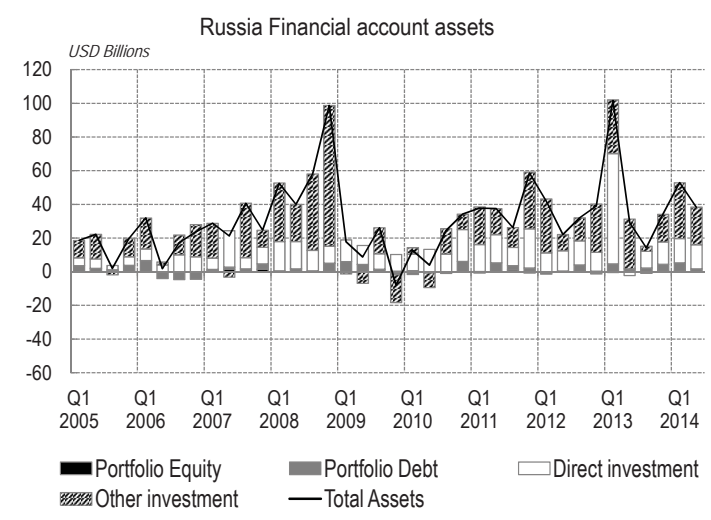

South Africa Financial account assets

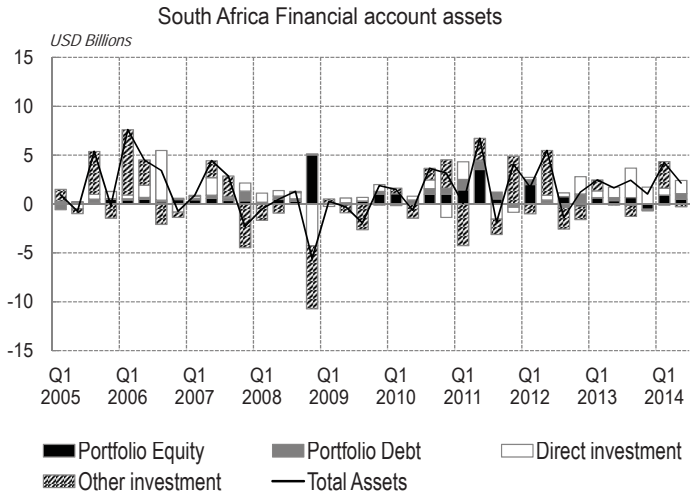

South Korea Financial account assets
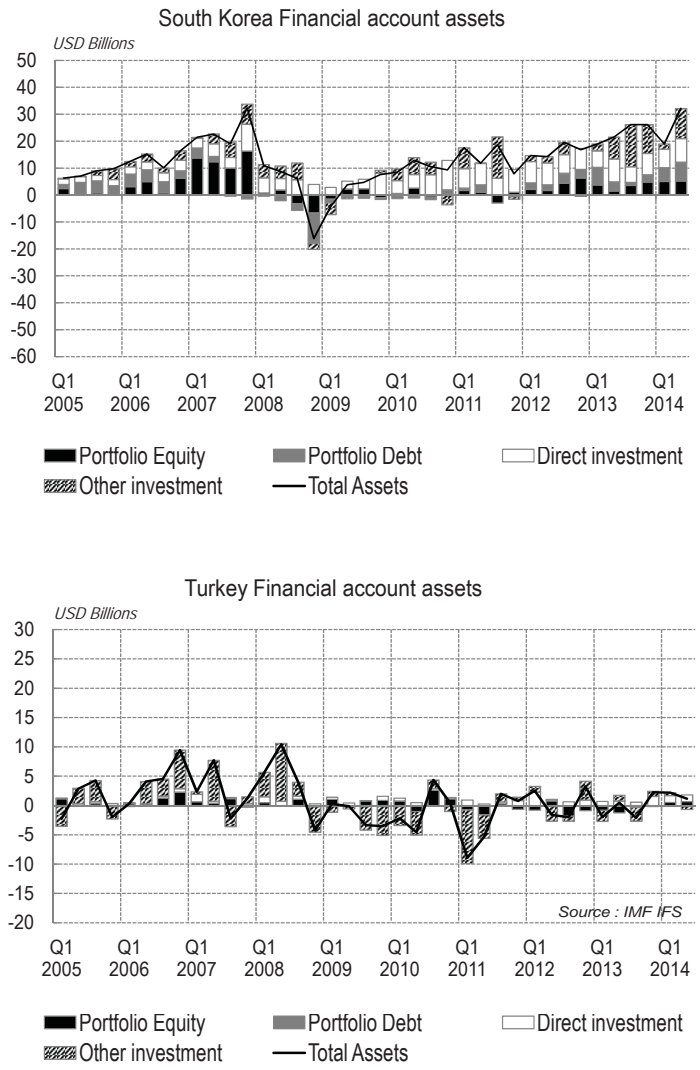
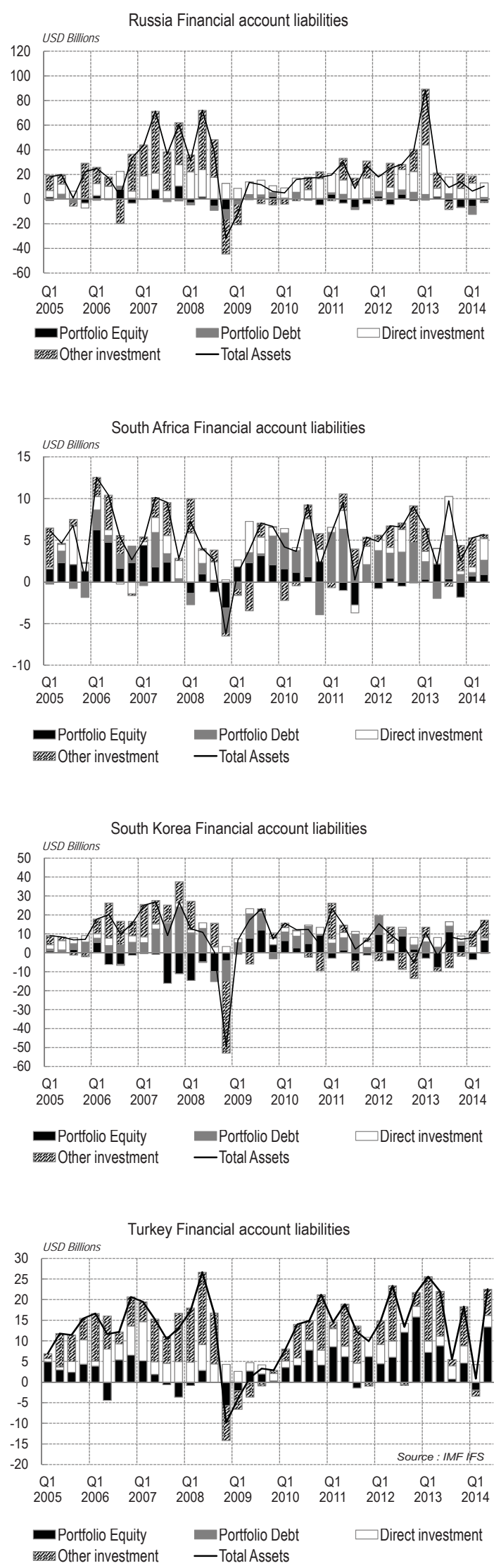
United Kingdom Financial account assets

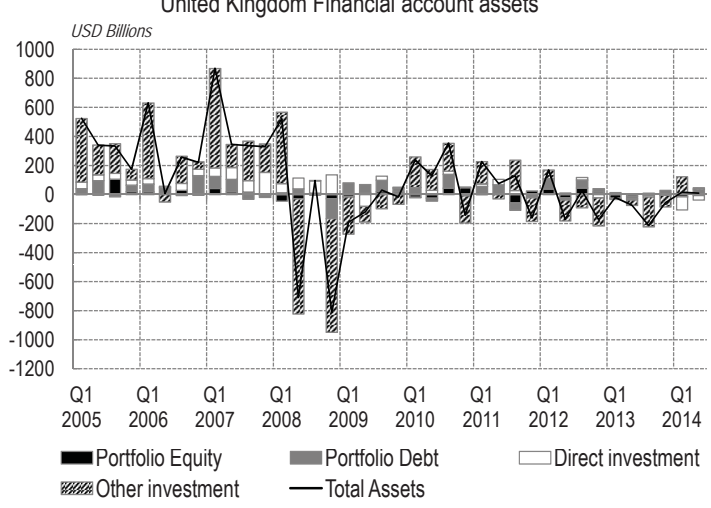

United States Financial account assets

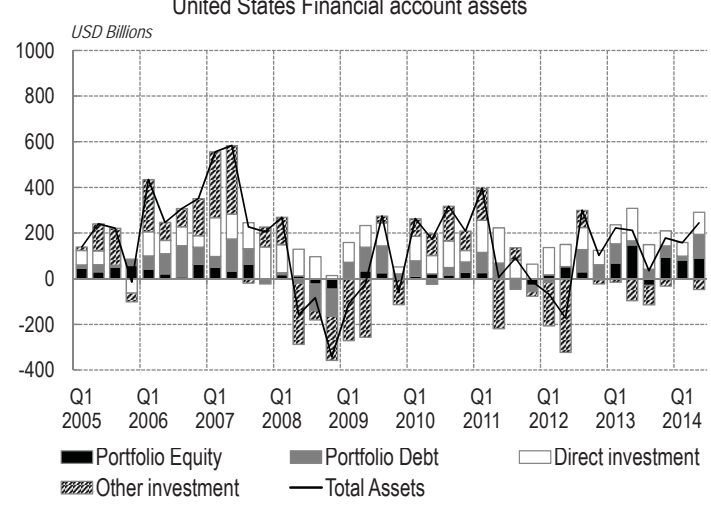

Euro area Financial account assets

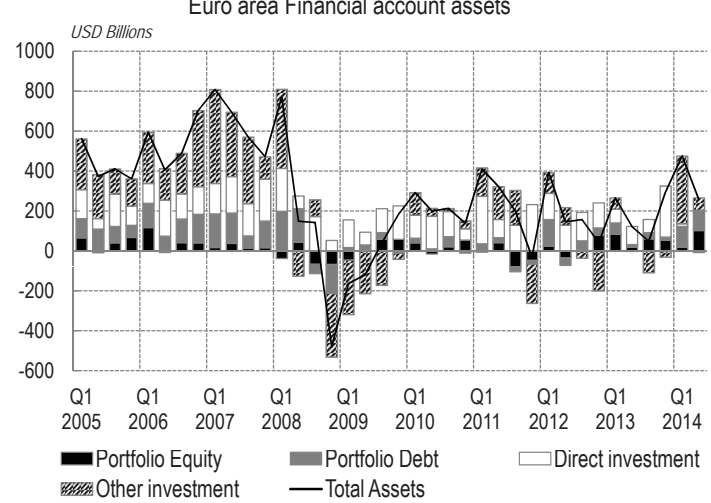

G20 Capital Outflows

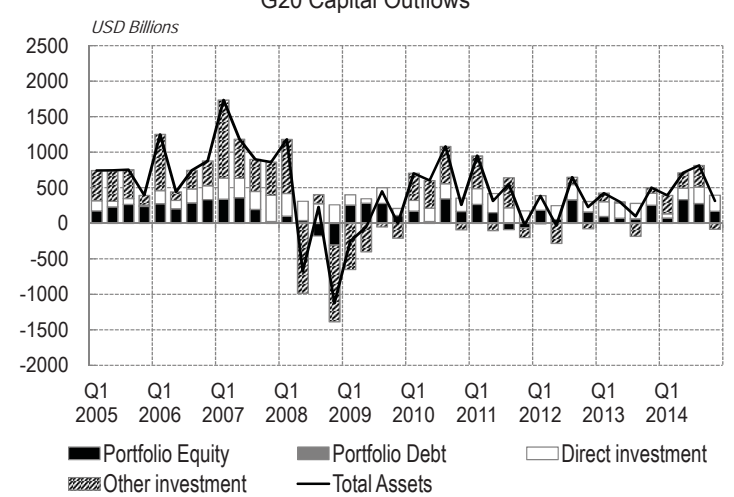

United Kingdom Financial account liabilities

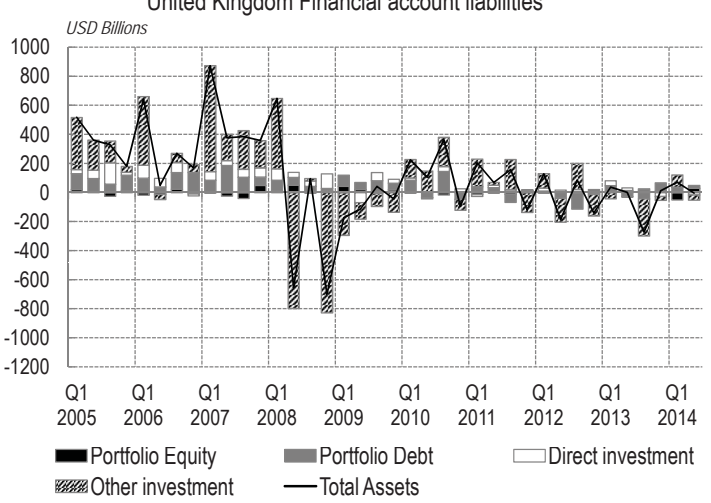

United States Financial account liabilities

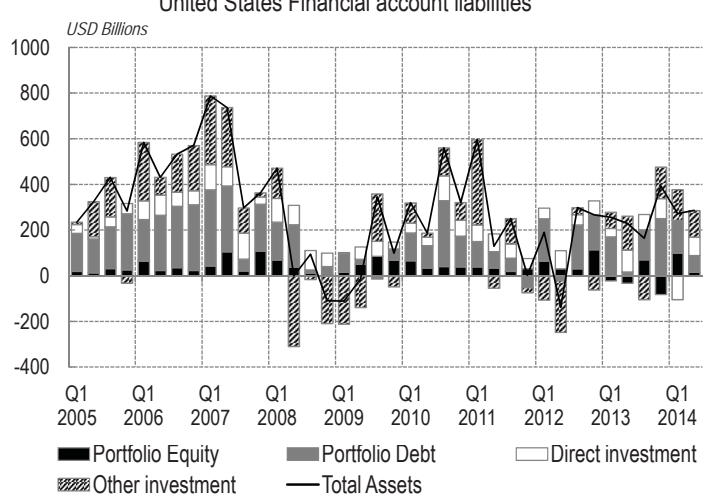

Euro area Financial account liabilities

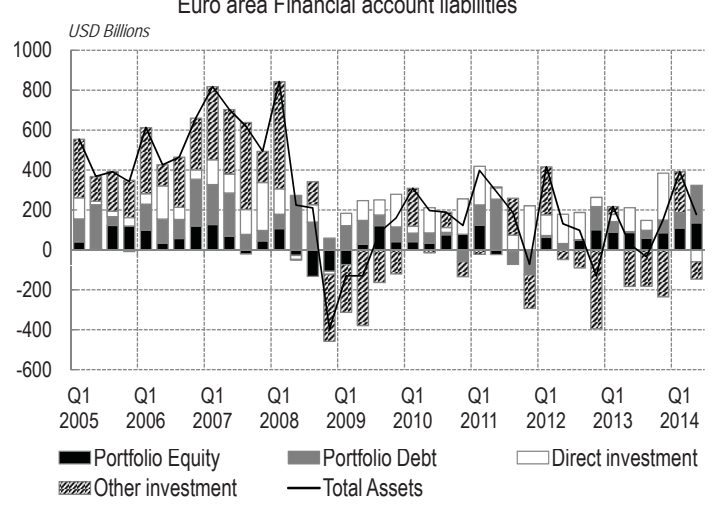

G20 Financial Capital Inflows

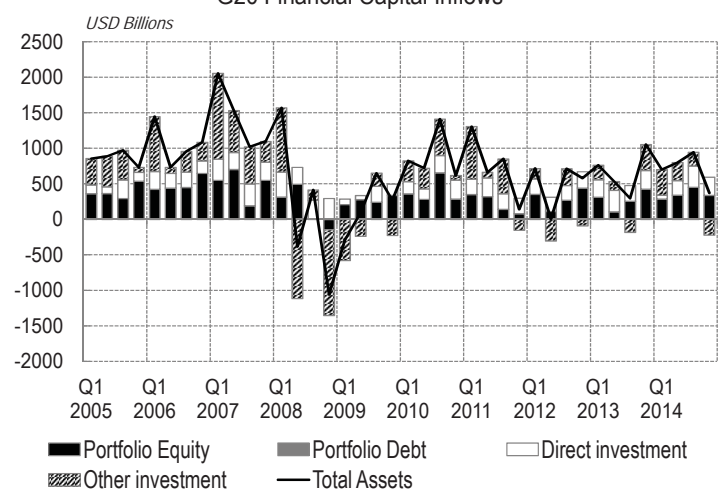




\section{Chart Appendix 2}

Chart - Balance of Payment Data for the G20 countries: Net Flows (percentage of GDP)
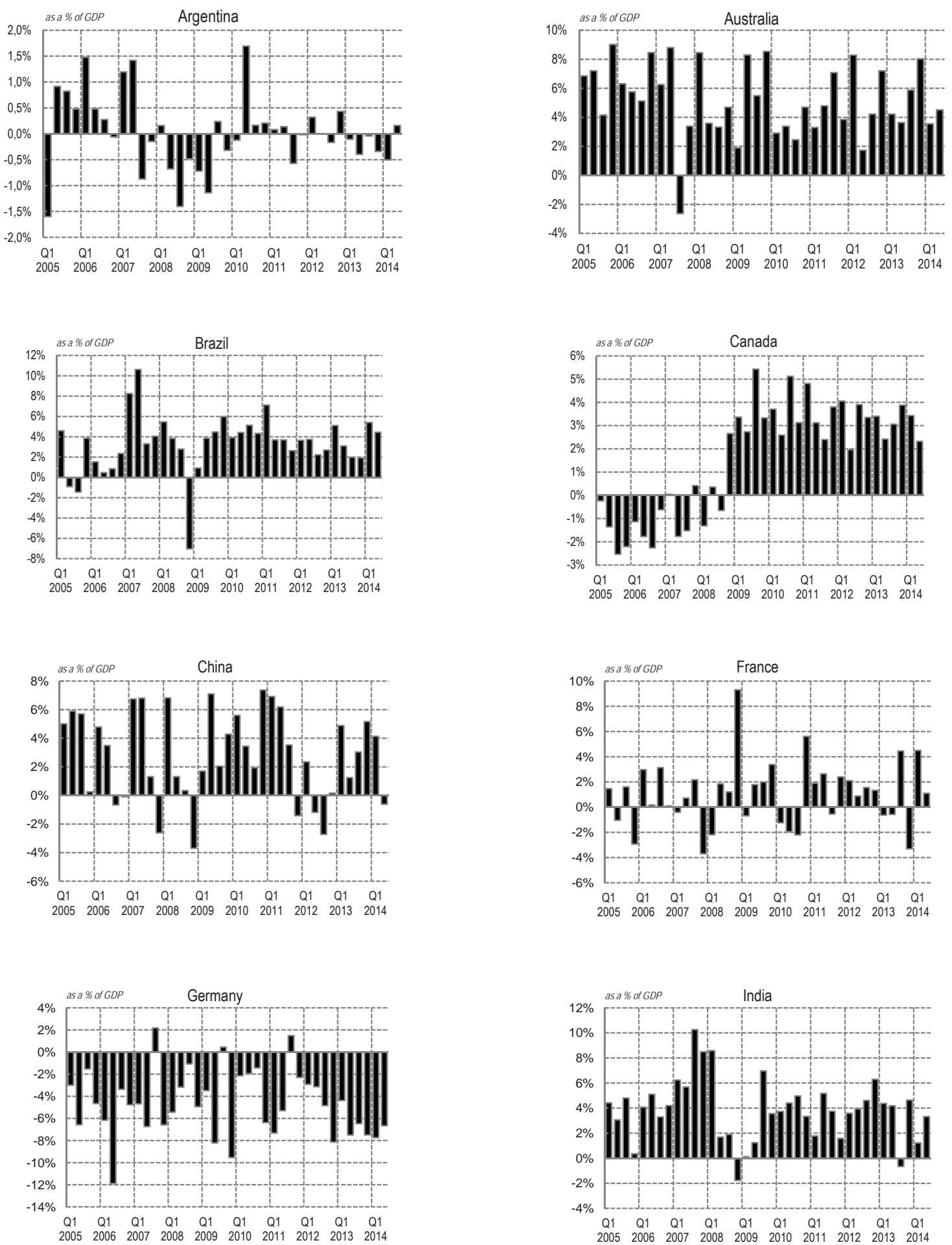

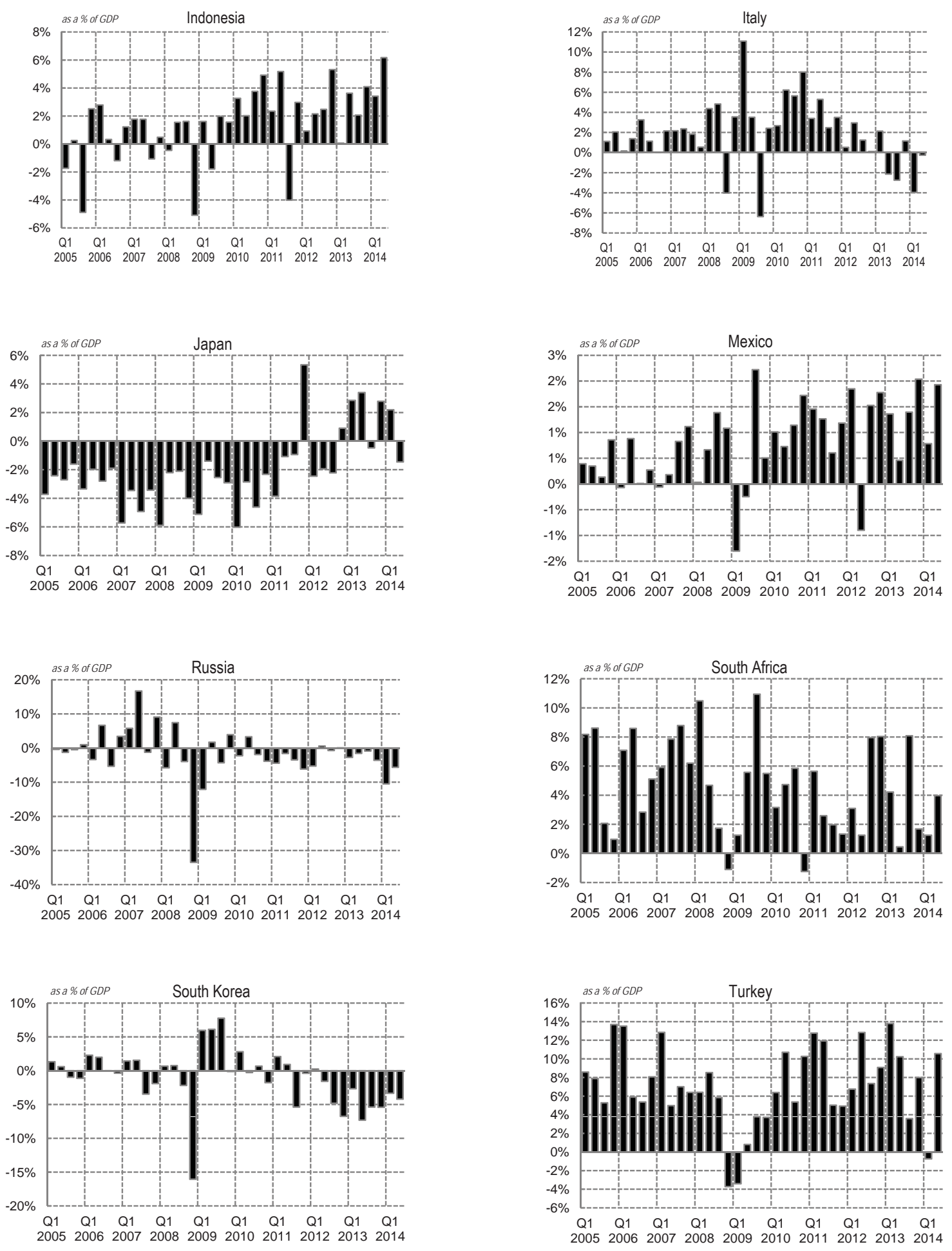

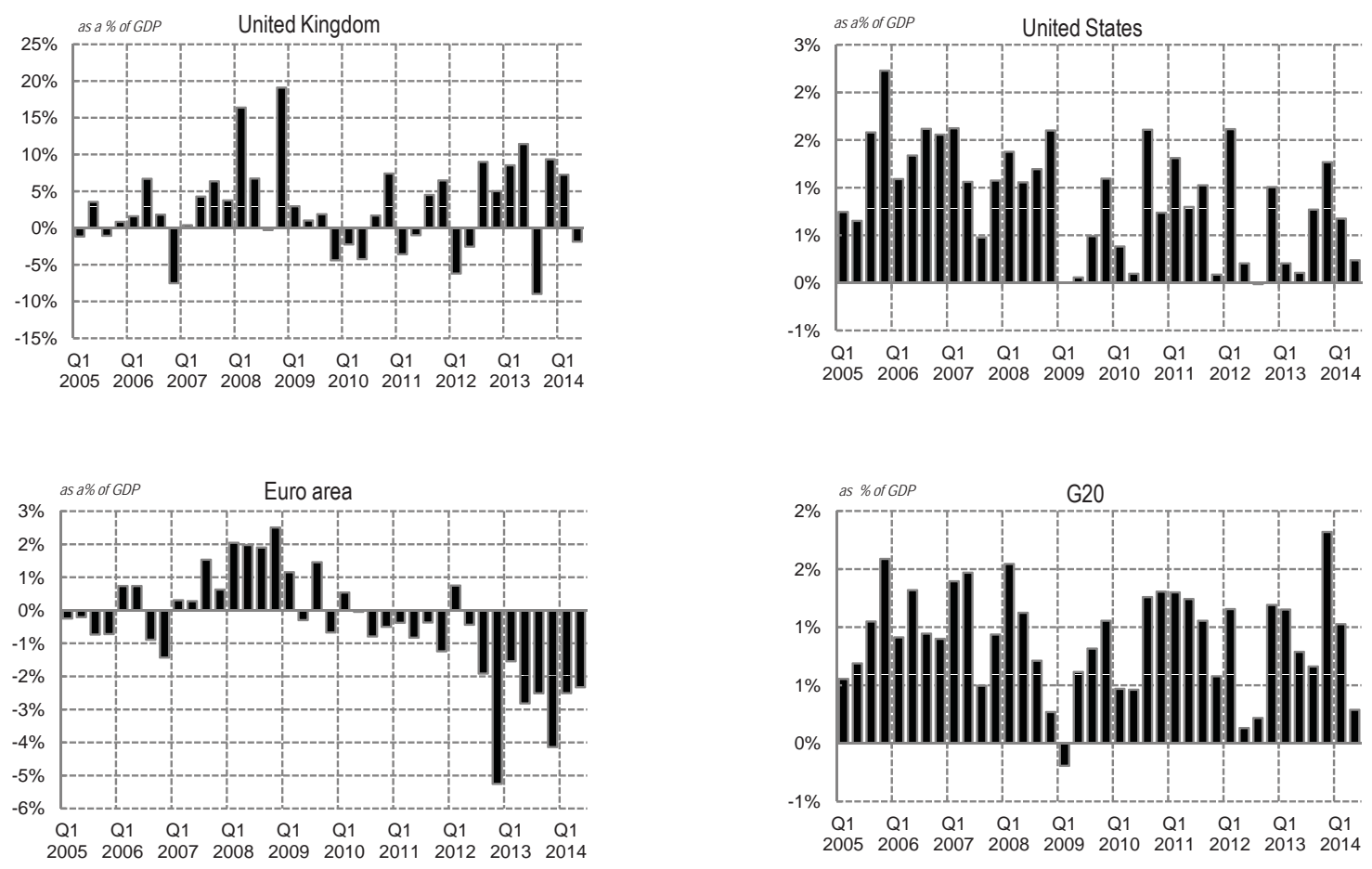

Chart - Current account imbalances (\% of World GDP)

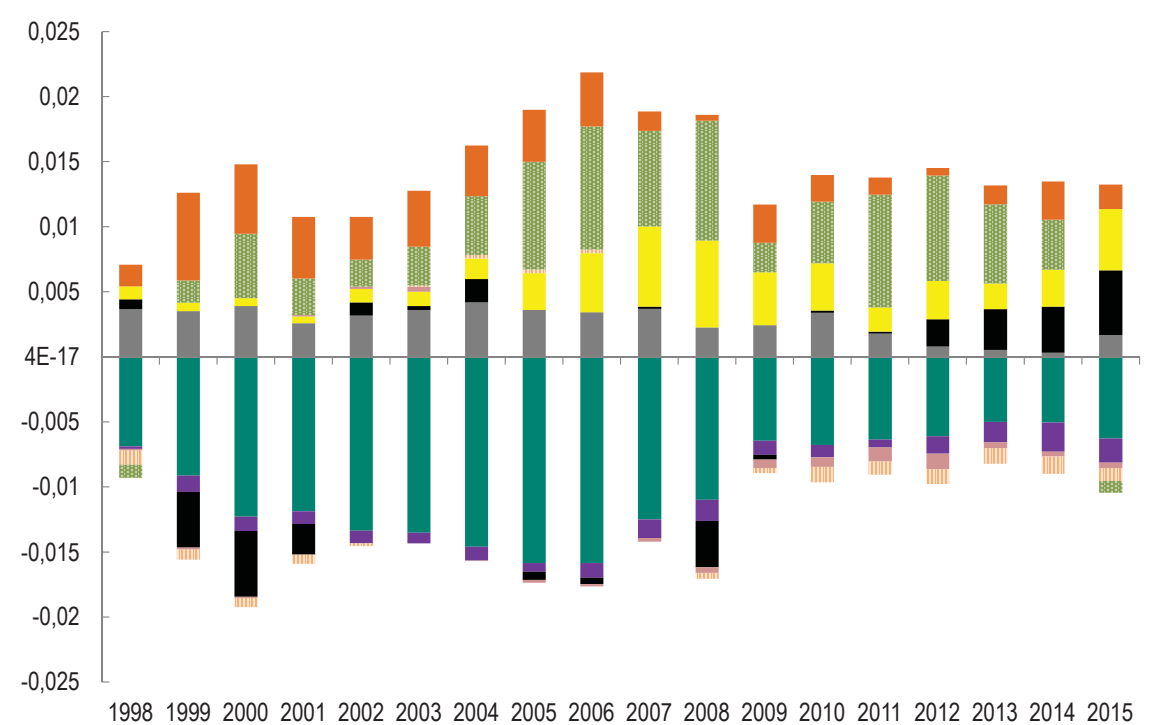

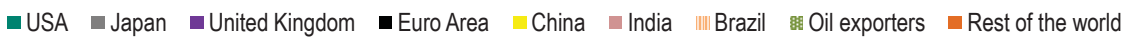




\section{Table Appendix 1}

Table 1 - Retrenchment ratio by country, absolute values (USD bn)

\begin{tabular}{|c|c|c|c|c|c|c|c|c|c|c|c|}
\hline & \multicolumn{5}{|c|}{ Outflows } & \multicolumn{5}{|c|}{ Inflows } \\
\hline & & $\begin{array}{l}\text { Portfolio } \\
\text { Equity }\end{array}$ & $\begin{array}{l}\text { Portfolio } \\
\text { Debt }\end{array}$ & $\begin{array}{c}\text { Direct } \\
\text { Investment }\end{array}$ & $\begin{array}{c}\text { Other } \\
\text { Investments }\end{array}$ & $\begin{array}{c}\text { Total } \\
\text { Assests }\end{array}$ & $\begin{array}{l}\text { Portfolio } \\
\text { Equity }\end{array}$ & $\begin{array}{l}\text { Portfolio } \\
\text { Debt }\end{array}$ & $\begin{array}{c}\text { Direct } \\
\text { Investment }\end{array}$ & $\begin{array}{c}\text { Other } \\
\text { Investments }\end{array}$ & $\begin{array}{c}\text { Total } \\
\text { Liabilities }\end{array}$ \\
\hline$A G$ & Argentina & - & 0.56 & -0.58 & 5.86 & 5.84 & -0.50 & -3.67 & 4.89 & -0.87 & -0.16 \\
\hline$A U$ & Australia & -4.40 & -2.67 & 0.34 & 17.60 & 10.88 & -2.60 & -17.21 & 45.42 & 5.80 & 31.41 \\
\hline AT & Austria & -2.84 & -44.66 & -36.83 & -67.58 & -151.91 & -6.45 & -51.33 & -41.75 & -53.23 & -152.76 \\
\hline BG & Belgium & 1.97 & -44.26 & -39.90 & -121.58 & -203.76 & 0.85 & 17.72 & -58.24 & -156.45 & -196.12 \\
\hline BR & Brazil & 0.99 & 5.18 & 2.03 & 24.97 & 33.17 & 0.97 & 13.99 & 59.88 & 9.75 & 84.59 \\
\hline CA & Canada & -2.53 & -23.02 & 11.54 & -13.96 & -27.97 & 7.68 & 35.13 & 5.75 & -5.91 & 42.64 \\
\hline $\mathrm{CL}$ & Chile & 5.14 & -2.55 & 11.76 & -4.36 & 9.99 & 4.15 & 7.85 & 14.28 & -4.34 & 21.95 \\
\hline $\mathrm{CH}$ & China & - & -51.51 & 54.75 & 201.82 & 203.10 & 8.68 & - & 155.57 & 26.61 & 220.92 \\
\hline $\mathrm{CZ}$ & Czech Republic & -1.17 & -0.65 & 2.28 & -0.37 & 0.09 & 0.53 & 1.05 & -1.28 & -1.52 & -1.22 \\
\hline DK & Denmark & -4.02 & 1.11 & -8.21 & -24.51 & -35.62 & 9.50 & -13.91 & -8.30 & -46.17 & -58.88 \\
\hline FN & Finland & -3.56 & -3.80 & -8.20 & -18.68 & -34.24 & -1.70 & 4.26 & -4.74 & -12.86 & -15.03 \\
\hline FR & France & -17.35 & -232.20 & -96.75 & -244.73 & -591.04 & -34.43 & -94.65 & -62.44 & -404.85 & -596.37 \\
\hline $\mathrm{DE}$ & Germany & 5.02 & -79.64 & -30.42 & -266.38 & -371.44 & -44.93 & -181.63 & -34.87 & -181.71 & -443.13 \\
\hline GR & Greece & -2.45 & 12.75 & -3.46 & -30.59 & -23.74 & -4.07 & -48.21 & -0.47 & 3.23 & -49.51 \\
\hline $\mathrm{HN}$ & Hungary & -1.50 & -0.37 & -16.84 & -5.37 & -24.08 & 0.35 & -6.42 & -17.35 & -17.25 & -40.67 \\
\hline ID & Indonesia & 0.69 & -1.43 & 6.99 & -0.69 & 5.56 & -0.32 & 9.05 & 17.48 & 8.48 & 34.70 \\
\hline IN & India & - & - & -3.36 & 14.96 & 12.06 & 5.97 & - & 12.78 & 20.75 & 46.19 \\
\hline $\mathbb{R}$ & Ireland & -1.19 & -87.29 & -15.93 & -189.24 & -293.66 & 14.26 & -133.44 & 18.22 & -191.68 & -292.64 \\
\hline IS & Israel & 1.35 & 0.91 & -5.17 & -8.03 & -10.94 & -1.08 & -1.88 & -0.48 & -5.88 & -9.32 \\
\hline IT & Italy & 32.68 & -92.82 & -31.59 & -119.48 & -211.21 & 26.23 & -105.87 & -21.15 & -157.75 & -258.54 \\
\hline$J P$ & Japan & -35.18 & -35.06 & 66.60 & 12.71 & 9.08 & -24.35 & -3.19 & -2.92 & 174.17 & 143.72 \\
\hline LX & Luxembourg & -18.64 & 16.88 & 251.54 & 60.11 & 309.90 & 11.81 & 107.03 & 332.86 & -140.24 & 311.47 \\
\hline MX & Mexico & - & -11.85 & 7.71 & 12.01 & 7.87 & 3.18 & 50.05 & 4.44 & -2.59 & 55.08 \\
\hline NL & Netherlands & 14.84 & -13.79 & -221.91 & -219.93 & -440.79 & -44.14 & -103.57 & -128.40 & -209.40 & -485.51 \\
\hline NZ & New Zealand & 2.04 & 4.10 & -1.31 & -1.05 & 3.78 & 2.04 & 3.37 & -0.62 & -10.25 & -5.45 \\
\hline NW & Norway & -0.65 & -1.20 & -9.80 & -42.65 & -54.30 & -6.29 & -7.99 & 1.25 & -43.70 & -56.73 \\
\hline PO & Poland & -0.78 & -0.28 & -5.18 & 0.15 & -6.10 & 3.70 & -1.24 & -8.98 & -8.32 & -14.84 \\
\hline PT & Portugal & -0.99 & -16.05 & 1.13 & -14.00 & -29.91 & -6.46 & -28.32 & 7.22 & -26.78 & -54.34 \\
\hline RM & Romania & -0.20 & 0.18 & -0.43 & -1.00 & -1.45 & 0.19 & 4.42 & -5.93 & -14.53 & -15.85 \\
\hline RS & Russia & -0.79 & 7.63 & 33.39 & 22.11 & 62.35 & -12.24 & 4.30 & 13.52 & -35.02 & -29.44 \\
\hline SA & South Africa & 0.27 & 0.44 & 1.93 & -4.12 & -1.48 & -10.40 & 4.88 & 2.45 & 2.09 & -0.98 \\
\hline KO & South Korea & -3.04 & 2.89 & 18.11 & 17.77 & 35.74 & 11.57 & -6.97 & -0.73 & -36.44 & -32.57 \\
\hline ES & Spain & 1.42 & -56.97 & -63.46 & -71.38 & -190.38 & 23.66 & -234.14 & -0.93 & -100.90 & -312.31 \\
\hline SD & Sweden & 9.73 & -10.87 & -21.80 & -19.41 & -42.35 & 2.19 & 14.63 & -24.38 & -23.49 & -31.05 \\
\hline sw & Switzerland & -4.18 & -40.49 & -42.09 & -117.41 & -204.17 & 5.29 & -2.28 & -25.21 & -116.68 & -138.88 \\
\hline TW & Taiwan & -5.95 & 11.23 & 6.34 & 16.07 & 27.70 & -18.53 & 1.65 & -1.90 & 17.21 & -1.58 \\
\hline TH & Thailand & 2.13 & 1.75 & 10.38 & -2.72 & 11.54 & -8.59 & 4.13 & 3.96 & 4.33 & 3.82 \\
\hline TK & Turkey & - & -4.03 & 3.50 & -8.58 & -9.09 & -0.86 & 14.48 & -4.33 & -0.26 & 9.03 \\
\hline UK & United Kingdom & -89.66 & -149.84 & -211.86 & -1157.62 & -1608.97 & 31.21 & -391.79 & -176.50 & -991.52 & -1528.61 \\
\hline US & United States & 108.44 & -103.70 & 123.42 & -819.10 & -690.93 & -43.92 & -396.28 & -33.93 & -612.76 & -1086.89 \\
\hline$N A$ & North America & 105.91 & -126.72 & 134.96 & -833.06 & -718.90 & -36.24 & -361.15 & -28.18 & -618.67 & -1044.24 \\
\hline$L A$ & Latin America & 6.13 & -8.67 & 20.92 & 38.49 & 56.87 & 7.80 & 68.21 & 83.50 & 1.95 & 161.46 \\
\hline$E E$ & Central \& East. Europe & -4.42 & 2.48 & 16.72 & 6.95 & 21.73 & -8.34 & 16.59 & -24.35 & -76.90 & -93.00 \\
\hline$W E$ & Western Europe & -79.88 & -843.11 & -589.54 & -2665.05 & -4177.59 & -23.47 & -1253.47 & -227.82 & -2854.19 & -4358.95 \\
\hline EmA & Emerging Asia & -4.62 & -39.96 & 75.11 & 229.44 & 259.97 & -12.80 & 51.58 & 187.89 & 77.38 & 304.05 \\
\hline AS & Asia & -40.57 & -30.74 & 83.75 & 47.04 & 59.47 & -13.34 & -23.99 & 41.16 & 133.28 & 137.11 \\
\hline$E M E$ & Emerging Countries & -2.91 & -46.15 & 112.75 & 274.87 & 338.57 & -13.35 & 136.39 & 247.03 & 2.43 & 372.51 \\
\hline$A D V$ & Advanced Countries & -14.55 & -1000.57 & -370.83 & -3451.07 & -4837.02 & -73.05 & -1638.61 & -214.84 & -3339.58 & -5266.08 \\
\hline WD & World & -15.83 & -1045.37 & -261.32 & -3188.36 & -4510.87 & -97.88 & -1499.22 & 34.17 & -3340.93 & -4903.86 \\
\hline
\end{tabular}


Table Appendix 2

Table 2 - Retrenchment ratio by country, relative terms (\% GDP)

\begin{tabular}{|c|c|c|c|c|c|c|c|c|c|c|c|}
\hline & \multicolumn{5}{|c|}{ Outflows } & \multicolumn{5}{|c|}{ Inflows } \\
\hline & & $\begin{array}{l}\text { Portfolio } \\
\text { Equity }\end{array}$ & $\begin{array}{l}\text { Portfolio } \\
\text { Debt }\end{array}$ & $\begin{array}{c}\text { Direct } \\
\text { Investment }\end{array}$ & $\begin{array}{c}\text { Other } \\
\text { Investments }\end{array}$ & $\begin{array}{c}\text { Total } \\
\text { Assests }\end{array}$ & $\begin{array}{l}\text { Portfolio } \\
\text { Equity }\end{array}$ & $\begin{array}{l}\text { Portfolio } \\
\text { Debt }\end{array}$ & $\begin{array}{c}\text { Direct } \\
\text { Investment }\end{array}$ & $\begin{array}{c}\text { Other } \\
\text { Investments }\end{array}$ & $\begin{array}{c}\text { Total } \\
\text { Liabilities }\end{array}$ \\
\hline AG & Argentina & - & 0.05 & -0.06 & 0.57 & 0.57 & -0.05 & -0.36 & 0.48 & -0.08 & -0.02 \\
\hline$A U$ & Australia & -0.56 & -0.34 & 0.04 & 2.25 & 1.39 & -0.33 & -2.20 & 5.80 & 0.74 & 4.01 \\
\hline AT & Austria & -0.86 & -13.44 & -11.08 & -20.34 & -45.72 & -1.94 & -15.45 & -12.56 & -16.02 & -45.98 \\
\hline BG & Belgium & 0.48 & -10.80 & -9.74 & -29.67 & -49.73 & 0.21 & 4.32 & -14.21 & -38.18 & -47.86 \\
\hline $\mathrm{BR}$ & Brazil & 0.09 & 0.49 & 0.19 & 2.36 & 3.14 & 0.09 & 1.32 & 5.66 & 0.92 & 8.00 \\
\hline CA & Canada & -0.20 & -1.83 & 0.92 & -1.11 & -2.22 & 0.61 & 2.79 & 0.46 & -0.47 & 3.39 \\
\hline $\mathrm{CL}$ & Chile & 3.55 & -1.76 & 8.11 & -3.00 & 6.89 & 2.86 & 5.41 & 9.85 & -2.99 & 15.13 \\
\hline $\mathrm{CH}$ & China & - & -2.05 & 2.18 & 8.02 & 8.07 & 0.34 & - & 6.18 & 1.06 & 8.78 \\
\hline$C Z$ & Czech Republic & -0.78 & -0.43 & 1.51 & -0.25 & 0.06 & 0.35 & 0.70 & -0.85 & -1.00 & -0.81 \\
\hline DK & Denmark & -1.44 & 0.40 & -2.93 & -8.76 & -12.73 & 3.40 & -4.97 & -2.97 & -16.50 & -21.05 \\
\hline FN & Finland & -1.64 & -1.75 & -3.78 & -8.63 & -15.81 & -0.78 & 1.97 & -2.19 & -5.94 & -6.94 \\
\hline FR & France & -0.75 & -9.99 & -4.16 & -10.53 & -25.42 & -1.48 & -4.07 & -2.69 & -17.41 & -25.65 \\
\hline DE & Germany & 0.17 & -2.65 & -1.01 & -8.87 & -12.37 & -1.50 & -6.05 & -1.16 & -6.05 & -14.76 \\
\hline GR & Greece & -0.92 & 4.76 & -1.29 & -11.43 & -8.87 & -1.52 & -18.01 & -0.17 & 1.20 & -18.50 \\
\hline $\mathrm{HN}$ & Hungary & -0.39 & -0.10 & -4.40 & -1.40 & -6.29 & 0.09 & -1.68 & -4.53 & -4.50 & -10.62 \\
\hline ID & Indonesia & - & - & -0.37 & 1.66 & 1.34 & 0.66 & - & 1.42 & 2.30 & 5.13 \\
\hline IN & India & 0.20 & -0.42 & 2.03 & -0.20 & 1.62 & -0.09 & 2.63 & 5.09 & 2.47 & 10.10 \\
\hline IR & Ireland & -0.52 & -37.91 & -6.92 & -82.19 & -127.53 & 6.19 & -57.95 & 7.91 & -83.25 & -127.09 \\
\hline IS & Israel & 0.88 & 0.59 & -3.37 & -5.24 & -7.13 & -0.71 & -1.23 & -0.31 & -3.83 & -6.07 \\
\hline IT & Italy & 1.68 & -4.79 & -1.63 & -6.16 & -10.89 & 1.35 & -5.46 & -1.09 & -8.13 & -13.33 \\
\hline$J P$ & Japan & -0.80 & -0.79 & 1.51 & 0.29 & 0.21 & -0.55 & -0.07 & -0.07 & 3.94 & 3.25 \\
\hline LX & Luxembourg & -8.10 & 7.33 & 109.24 & 26.11 & 134.59 & 5.13 & 46.48 & 144.56 & -60.90 & 135.27 \\
\hline MX & Mexico & - & -0.32 & 0.21 & 0.32 & 0.21 & 0.08 & 1.34 & 0.12 & -0.07 & 1.47 \\
\hline NL & Netherlands & 2.05 & -1.90 & -30.64 & -30.37 & -60.86 & -6.09 & -14.30 & -17.73 & -28.91 & -67.04 \\
\hline NZ & New Zealand & 1.78 & 3.57 & -1.14 & -0.92 & 3.29 & 1.78 & 2.94 & -0.54 & -8.92 & -4.75 \\
\hline NW & Norway & -0.19 & -0.36 & -2.92 & -12.71 & -16.18 & -1.87 & -2.38 & 0.37 & -13.02 & -16.90 \\
\hline PO & Poland & -0.23 & -0.08 & -1.54 & 0.04 & -1.81 & 1.10 & -0.37 & -2.67 & -2.47 & -4.41 \\
\hline PT & Portugal & -0.48 & -7.69 & 0.54 & -6.71 & -14.33 & -3.09 & -13.57 & 3.46 & -12.83 & -26.04 \\
\hline RM & Romania & -0.17 & 0.15 & -0.37 & -0.85 & -1.24 & 0.16 & 3.77 & -5.06 & -12.39 & -13.52 \\
\hline RS & Russia & -0.09 & 0.82 & 3.61 & 2.39 & 6.74 & -1.32 & 0.46 & 1.46 & -3.78 & -3.18 \\
\hline SA & South Africa & 0.10 & 0.16 & 0.72 & -1.54 & -0.55 & -3.88 & 1.82 & 0.91 & 0.78 & -0.36 \\
\hline KO & South Korea & -0.31 & 0.30 & 1.85 & 1.82 & 3.66 & 1.18 & -0.71 & -0.07 & -3.73 & -3.33 \\
\hline ES & Spain & 0.11 & -4.55 & -5.07 & -5.70 & -15.20 & 1.89 & -18.70 & -0.07 & -8.06 & -24.94 \\
\hline SD & Sweden & 2.33 & -2.60 & -5.21 & -4.64 & -10.13 & 0.52 & 3.50 & -5.83 & -5.62 & -7.43 \\
\hline SW & Switzerland & -0.98 & -9.50 & -9.87 & -27.54 & -47.88 & 1.24 & -0.53 & -5.91 & -27.36 & -32.57 \\
\hline TW & Taiwan & -1.55 & 2.93 & 1.66 & 4.20 & 7.23 & -4.84 & 0.43 & -0.50 & 4.49 & -0.41 \\
\hline TH & Thailand & 0.99 & 0.81 & 4.82 & -1.27 & 5.36 & -3.99 & 1.92 & 1.84 & 2.01 & 1.78 \\
\hline TK & Turkey & - & -0.78 & 0.67 & -1.65 & -1.75 & -0.17 & 2.79 & -0.83 & -0.05 & 1.74 \\
\hline UK & United Kingdom & -3.47 & -5.81 & -8.21 & -44.86 & -62.35 & 1.21 & -15.18 & -6.84 & -38.42 & -59.23 \\
\hline US & United States & 0.20 & -0.19 & 0.23 & -1.50 & -1.27 & -0.08 & -0.73 & -0.06 & -1.12 & -1.99 \\
\hline$N A$ & North America & 0.19 & -0.23 & 0.24 & -1.49 & -1.29 & -0.06 & -0.65 & -0.05 & -1.11 & -1.87 \\
\hline$L A$ & Latin America & 0.10 & -0.15 & 0.35 & 0.64 & 0.95 & 0.13 & 1.14 & 1.40 & 0.03 & 2.70 \\
\hline EE & Central \& East. Europe & -0.18 & 0.10 & 0.69 & 0.29 & 0.89 & -0.34 & 0.68 & -1.00 & -3.16 & -3.82 \\
\hline WE & Western Europe & -0.53 & -5.55 & -3.88 & -17.56 & -27.52 & -0.15 & -8.26 & -1.50 & -18.80 & -28.72 \\
\hline EmA & Emerging Asia & -0.12 & -1.00 & 1.89 & 5.77 & 6.54 & -0.32 & 1.30 & 4.72 & 1.95 & 7.64 \\
\hline AS & Asia & -0.64 & -0.49 & 1.33 & 0.75 & 0.94 & -0.21 & -0.38 & 0.65 & 2.12 & 2.18 \\
\hline EME & Emerging Countries & -0.02 & -0.36 & 0.88 & 2.15 & 2.65 & -0.10 & 1.07 & 1.94 & 0.02 & 2.92 \\
\hline$A D V$ & Advanced Countries & -0.02 & -1.29 & -0.48 & -4.46 & -6.26 & -0.09 & -2.12 & -0.28 & -4.32 & -6.81 \\
\hline WD & World & -0.02 & -1.16 & -0.29 & -3.52 & -4.98 & -0.11 & -1.66 & 0.04 & -3.69 & -5.42 \\
\hline
\end{tabular}




\section{Previous Issues}

Transatlantic Trade: Whither Partnership, Which Economic Consequences? by Lionel Fontagné, Julien Gourdon \& Sébastien Jean, No 1, September 2013. Can the Euro Area Avoid a "Lost Decade"? by Benjamin Carton, Jérôme Héricourt \& Fabien Tripier, No 2, April 2014.

China's Roadmap to Harmonious Society - Third Plenum Decisions on "major issues concerning comprehensively deepening reforms" by Michel Aglietta \& Guo Bai, No 3, May 2014.

A New Architecture for Public Investment in Europe: The Eurosystem of Investment Banks and the Fede Fund by Natacha Valla, Thomas Brand \& Sébastien Doisy, No 4, July 2014.

Central Bank Currency Swaps and the International Monetary System? by Christophe Destais, No 5, September 2014

Financing energy and low-carbon investment: public guarantees and the ECB by Michel Aglietta \& Étienne Espagne, № 6, March 2015.

A Holistic Approach to ECB Ass et Purchases, the Investment Planand CMU by Natacha Valla, Jesper Berg, Laurent Clerc, Olivier Garnier \& Erik Nielsen, № 7, April 2015.

Currency Turmoil in an Unbalanced World Economy by Michel Aglietta \& Virginie Coudert, No 8, July 2015.

Climate Finance at COP21 and After: Lessons Learnt, Étienne Esâgne, No 9, February 2016.

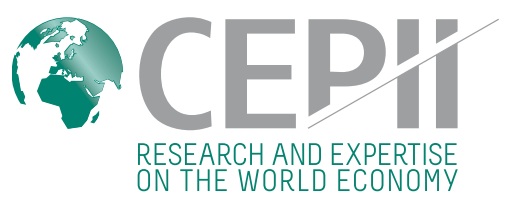

CEPII (Centre d'Etudes Prospectives et d'Informations Internationales) is a French institute dedicated to producing independent, policy-oriented economic research helpful to understand the international economic environment and challenges in the areas of trade policy, competitiveness, macroeconomics, international finance and growth.
CEPII Policy Brief

CEPII's insights on international economic policy

CEPII - Paris - 2016

No ISSN: 2270-258X

All rights reserved. Opinions expressed in this publication are those of the author(s) alone.

Editorial Director: Sébastien Jean

Managing Editor: Natacha Valla

Production: Laure Boivin
CEPII

113 , rue de Grenelle

75007 Paris

+33153685500

www.cepii.fr

Press contact: presse@cepii.fr 